\title{
EAST ANTARCTIC ICE SHEET STABILITY RECORDED IN A HIGH-ELEVATION ICE- CORED MORAINE
}

Nicole A. Bader ${ }^{\text {a }}$, Kathy J. Licht ${ }^{a^{*}}$, Michael R. Kaplan ${ }^{\text {b }}$, Christine Kassab ${ }^{\text {a }}$, and Gisela Winckler ${ }^{\mathrm{b}}$

${ }^{a}$ Department of Earth Sciences, Indiana University- Purdue University Indianapolis, Indianapolis, IN, USA

${ }^{\mathrm{b}}$ Lamont- Doherty Earth Observatory, Palisades, NY, USA

* Corresponding author

Email address: klicht@iupui.edu

Key words:

Provenance

Outlet glacier

Detrital zircon

Till

Lithology

Antarctica

Transantarctic Mountains 


\begin{abstract}
Till in an extensive blue ice moraine in the central Transantarctic Mountains at Mt. Achernar shows relatively continuous deposition by East Antarctic derived ice throughout the last glacial cycle. The most recently exposed material along the active margin of the Law Glacier (Zone 1) has hummocky topography that transitions into to a relatively flat region (Zone 2), followed by a series of $\sim 2 \mathrm{~m}$ high continuous, parallel/sub-parallel ridges and troughs (Zones 35). The entire moraine is ice-cored. Past surface changes of $<40 \mathrm{~m}$ are indicated by a lateral moraine at the base of Mt. Achernar and substantial topographic relief across Zone 3.

Pebble lithology and detrital zircon geochronology were analyzed on samples along a 6.5 $\mathrm{km}$ transect across the moraine which formed from sub- and englacial debris. Beacon and Ferrar Supergroup rocks comprise most rock types on the moraine surface. Overall, pebbles in Zones 1, 4 and 5 are dominated by igneous rocks of the Ferrar dolerite, whereas Zones 2 and 3 have $40 \%$ more Beacon Supergroup sedimentary rocks. Zone 4 is characterized by distinctly colored lithologic bands, 5-20 m wide, that alternate between dominant Beacon and Ferrar rock types. When combined with surface exposure ages, we conclude that Zones 2 and 3 contain sediment accumulated through the last glacial maximum (LGM). In contrast to pebble data, the U-Pb zircon data from till across all zones show little variability and are consistent with a Beacon Supergroup source, as samples show significant populations from the Proterozoic, 550-600 Ma and $~ 950-1270 \mathrm{Ma}$, as well as the late Archean 2700-2770 Ma. The Mackellar, Fairchild, and lower Buckley Formations are interpreted as dominant sources of the detrital zircons. The zircon data lack the spatio-temporal variability indicated by the pebble fraction because the local Ferrar dolerite is not zircon bearing, highlighting the broader importance of using multiple techniques when interpreting provenance changes over time.

Rather than reflecting major changes in ice flow path over time, the provenance changes are interpreted to indicate relative stability of the East Antarctic ice sheet, as the Law Glacier tapped into and eroded successively lower stratigraphic units of the Beacon Supergroup. This has important implications for interpreting offshore provenance records.
\end{abstract}




\section{Introduction}

Antarctica is the reservoir for $\sim 70 \%$ of the world's fresh water and plays an influential role in global climate change and ocean circulation patterns. The behavior of the East Antarctic ice sheet (EAIS), has long been considered relatively stable because most of the ice sheet was thought to rest on bedrock above sea level making it less susceptible to changes in climate and sea level rise (i.e., Mercer, 1983). However, recent studies show widespread water beneath the EAIS (Siegert et al., 2005; Wingham et al., 2006; Stearns et al., 2008), higher melt potential from impinging ocean water (Greenbaum et al., 2015), as well as dynamic ice behavior in response to climatic warmth during the Pliocene (e.g., Cook et al., 2013). In contrast, the West Antarctic Ice Sheet (WAIS) is a marine based ice sheet that is mostly grounded below sea level, which makes it much more susceptible to changes in sea level and variations in ocean temperatures (e.g., Hollin, 1962; Joughin and Alley, 2011; Rignot et al., 2014). The EAIS and WAIS are coupled and therefore reconstructions of both are needed to provide modelers with essential parameters that are used to predict ice sheet response to changes in climate. A relatively small rise in sea level would undoubtedly have worldwide detrimental economical and societal impacts.

Antarctic ice sheet evolution both during and since the last glacial maximum (LGM) has been studied extensively (e.g., RAISED Consortium, 2014). However, pre-LGM glacial deposits and ice sheet flow reconstructions are less common because readvance and thickening of ice typically modifies or destroys previous records of glacial events. Limited constraints on preLGM fluctuations of the EAIS are directly related to this relative lack of deposits to analyze. However, several recent studies now suggest that pre-LGM records may be preserved in the blue ice regions at the head of outlet glaciers in the Transantarctic Mountains and EllsworthWhitmore Mountains (e.g., Bromley et al., 2010; Ackert et al., 2011, 2013; Hein et al., 2016), 
providing valuable information to help fill this data gap. Furthermore, compositional and provenance studies of glacial till and pebbles deposited in blue-ice moraines provide insight to past ice sheet configurations, and also reveal what is being eroded from beneath the ice sheet (Palmer et al., 2012).

This study focuses on the blue-ice moraine sequence at the base of Mt. Achernar, along the Law Glacier, Antarctica (Fig. 1). Multiple provenance techniques and geomorphic observations are utilized in order to test three hypotheses that all bear on former EAIS dynamics and history: (1) the moraine sequence at Mt. Achernar contains a mixture of subglacially derived sediment and locally-exposed rock types, (2) till composition within the moraine varies through time, (3) and moraine morphology reflects Quaternary changes in the ice flow dynamics of the EAIS. This research is the first multiproxy dataset documenting provenance variations in debris accumulating along a transect of an East Antarctic moraine sequence through time and space. These data provide a more detailed understanding of the dynamics of the EAIS, which in turn provide additional constraints resulting in more accurate ice sheet models to explain past and predict future ice sheet dynamics. This study also evaluates whether different provenance methods provide similar information about the sources of glacial debris.

\section{Background and Geologic Setting}

\subsection{Transantarctic Mountains}

The Transantarctic Mountains (TAM) are approximately 3,500 km long, 100-200 km wide, reach heights up to $4.5 \mathrm{~km}$ and divide East and West Antarctica. The bedrock exposed in the Transantarctic Mountains reveals Antarctica's Precambrian to Jurassic history and has been eroded, transported, and deposited to form the Quaternary sedimentary record. The lithology and geochronology of the bedrock units are the basis of provenance studies such as this one that aim to reconstruct ice sheet history. Here we briefly summarize the relevant bedrock geology both 
regionally and at Mt. Achernar as needed to interpret data obtained from the glacial deposits.

Throughout much of the TAM, the Cambrian-Ordovician Ross Orogeny is recorded in deformed and metamorphosed Neoproterozoic and Cambrian sedimentary and volcanic basement rock, as well as by the intrusion of granitoid batholiths known as the Granite Harbour Intrusives (Stump, 1995; Fitzgerald, 2002). The oldest outcrops of the Granite Harbor suite have been dated to $545 \mathrm{Ma}$ using U-Pb of zircons and the youngest $480 \mathrm{Ma}$ (Goodge et al., 2012; Paulsen et al., 2013). The Ross Orogeny ceased around $480 \mathrm{Ma}$ and was followed by exhumation and as much as $\sim 15-20 \mathrm{~km}$ erosion of the basement rock to form the Kukri Erosion Surface (Stump, 1995). This was followed by sedimentation into extensive basins, forming the Beacon Supergroup (e.g., Barrett, 1991; Isbell, 1999). These basins were flanked by a pre-Cambrian craton on one side and highlands that included a Permian magmatic arc on the other (Barrett, 1991). The Victoria Group consists of sediments deposited from the Permian to early Jurassic (Fig. 2). The oldest formation of the Victoria Group is the Pagoda tillite, which is characterized by massive, poorly sorted sandstones/diamictites (Isbell et al., 2008). The remaining formations of the Victoria Group, the Mackellar, Fairchild, Buckley, Fremouw, and Falla Formations, are indicative of alluvial sedimentation and shift between East and West Antarctic sediment sources over time (Barrett, 1991; Faure and Mensing, 2010; Elliot et al., 2014). Changes in sediment sources are reflected in both compositional differences (arkose vs quartz arenite) and zircon U$\mathrm{Pb}$ ages (Fig. 2; Supplementary Figure 1). Most formations are not a single rock type and include interbedded sandstones and coal/carbonaceous shale (Fig. 2). The onset of rifting of Gondwana that began in the Jurassic was accompanied by tholeitic magmatism 184-183 Ma, which is manifest as the intrusion of dikes and sills of the Ferrar dolerite and its extrusive equivalent, the Kirkpatrick basalt (Encarnación et al., 1996).

As noted above, temporal variations in sediment sources to the Beacon basin are apparent 
in detrital zircon ages (Elliot and Fanning, 2008; Elliot et al., 2014). The Pagoda and Mackellar Formations have zircon grains dominantly 600-580 Ma, the Fairchild and lower Buckley Formations contain slightly younger zircons with peaks 555 and $525 \mathrm{Ma}$, respectively (Fig. 2). In sharp contrast, zircons from the upper Buckley Formation are primarily 260-240 Ma indicating a switch from East to a West Antarctic source. The overlying Fremouw Formation has broadly distributed ages lacking distinct age peaks, but show a roughly bimodal distribution of zircons with clusters of ages in the late Paleozoic and Cambrian-Late Proterozoic reflecting input from both East and West Antarctic terranes.

\subsection{Antarctic Ice Sheet Evolution}

Today, two main ice sheets dominate the Antarctic continent. The WAIS is a marinebased ice sheet where much of the bed lies beneath sea level, as much as 2,000 $\mathrm{m}$ in some regions (Fretwell et al., 2012). In contrast, the EAIS is mostly grounded above sea level, although there are extensive elongate basins below sea level (Fretwell et al., 2012). One of these basins extends parallel to the inland margin of the Transantarctic Mountains (i.e., Wilkes Subglacial Basin), thus the bed topography beneath catchments of the East Antarctic outlet glaciers decrease (by several kilometers) inland of the TAM. Both the EAIS and WAIS drain into the Ross Embayment and converge in the Ross Ice Shelf. Studies indicate that ice shelves provide an important buttressing impact on upstream ice and therefore affect ice sheet stability (i.e., Dupont and Alley, 2005).

During the LGM, advance of grounded ice in the Ross Sea resulted in substantial thickening of ice at the mouths of East Antarctic outlet glaciers (>1,000 m) but little elevation change at the heads of the EAIS outlet glaciers (e.g., Mercer, 1983; Hall et al., 2013). As ice thinned, boulders and till were left perched along mountain faces marking the maximum ice elevation and deposition at successively lower elevations. For example, surface exposure dating 
with cosmogenic nuclides at Reedy Glacier, another outlet of the EAIS located $\sim 600 \mathrm{~km}$ southeast of our study area, reveals that boulders perched along vertical transects are LGM and younger (Bromley et al., 2010). However, the boulders in laterally accumulating glacial deposits (drift sheets) at the heads of some outlet glaciers along the polar plateau, including the Reedy and Beardmore Glaciers, can preserve records over multiple glacial cycles (Mercer, 1972; Bromley et al., 2010).

\subsection{Law Glacier and Mt. Achernar}

The $20 \mathrm{~km}$ wide Law Glacier is located between the Queen Alexandra and Queen Elizabeth Ranges, flows past Mt. Achernar, and feeds into the Bowden Névé (Fig. 1). The Law Glacier contains blue ice areas characterized by sun-cupped ice produced when rates of sublimation and wind scouring processes exceed snow accumulation (Bintanja, 1999). Isolated mountain peaks, nunataks, with irregular surface topography can induce a microclimate of increased localized wind turbulence. Such settings are favorable for the formation of blue ice areas while simultaneously acting as a barrier to ice flow of the main outlet glacier, resulting in upward ice flow trajectories (Whillans and Cassidy, 1983; Bintanja, 1999). This upward direction of ice flow, enhanced by high sublimation rates, allows for the formation of blue-ice moraines as rocks and till accumulate at the ice surface (Fig. 3).

Mt. Achernar moraine (MAM), the focus of this study, is near the head of the Law Glacier and occurs at an elevation of $\sim 1700-1900 \mathrm{~m}$. It is an extensive blue-ice moraine complex (Fig. 1) that has formed downstream of Mt. Achernar (2691 m) and has been described as representing time-transgressive accumulation of glacial debris. This is based on ${ }^{10} \mathrm{Be}$ and ${ }^{26} \mathrm{Al}$ surface exposure ages increasing from $\sim 30$ to $>300$ ka away from the Law Glacier (Hagen, 1995). The ice-cored MAM extends approximately $15 \mathrm{~km}$ downstream from Mt. Achernar and $>5 \mathrm{~km}$ from Law Glacier to the Lewis Cliff Ice Tongue. This ice tongue, and another unnamed 
one, flows over Lewis Cliff and into the southern part of the moraine (Fig. 4). The glaciallyderived material on the MAM accumulates in the manner that Whillans and Cassidy (1983) described for the concentration of meteorites on the plateau of the EAIS side of the TAM, except that the rocks and till in the moraine have been eroded from subglacial bedrock (Palmer et al., 2012).

The bedrock geology of Mt. Achernar consists of flat-lying, Permian sandstones and coal seams of the Buckley Formation (Beacon Supergroup) intruded by three Ferrar dolerite sills (Barrett and Elliot, 1973). The contact between the lower and upper Buckley occurs midway up the exposed bedrock at Mt. Achernar, several hundred meters above the moraine surface (Isbell, 1990). The Jurassic Ferrar dolerite sills that intruded the Buckley Formation typically cause contact metamorphism (i.e., Bernet and Gaupp, 2005). No other rock types are exposed along Law Glacier upstream of the moraine. However, the bedrock walls adjacent to the unnamed ice tongue (UNIT; Fig. 1) and Zone 5 till samples are the only place where Pagoda, Mackellar, and Fairchild Formations are exposed in at least three fault slices on the east facing wall (Elliot, personal comm.) and relatively abundant Cambrian Shackleton limestone and Douglas conglomerate (Byrd Group) float occur on the west facing hillside.

\section{Methods}

\subsection{Data and Sample Acquisition}

A Trimble rover GPS backpacking system was used to create a topographic profile (which was differentially processed) across the main MAM sampling transect (Figs. 4 \& 5) from the ice margin (Zone 1) back through Zone 4. Till, pebble and cobble samples were collected along this transect to evaluate provenance change over time. Zone 5 samples are slightly offset from the main transect and are sourced by ice from the UNIT rather than Law Glacier (Fig. 4). A second sampled transect, hereafter referred to as the "tail", is located along the ice edge 
(equivalent to Zone 1), downstream from the main transect (Fig. 4). These samples were collected to assess spatial variability in provenance under an a priori assumption that samples near the ice margin have similar relative age.

To develop a representative collection of rock types at the MAM, all pebble to coarse gravel size rock fragments were collected from twenty-six $1 \mathrm{~m}^{2}$ sites (Table 1). More than 1500 pebbles were collected in total and compared to a reference collection of regionally mapped bedrock obtained from the Polar Rock Repository. Cluster analysis was run on all sampling sites using Paleontological Statistics software (PAST) (Hammer et al., 2001) and was based on rock types listed in Supplementary Table 1. A non-random sampling of more than 50 cobbles and large pebbles from across the main transect and along the tail targeted material that was representative of the local lithology as well as rock types that were inferred to be exotic.

To characterize the sediment across the moraine, approximately $1 \mathrm{~kg}$ of bulk till was collected from 36 sites. The top 1-2 cm of sediment was removed before collection to avoid particle size biasing due to wind deflation. Till samples were thoroughly homogenized before subsampling for particle size analysis and $\mathrm{U}-\mathrm{Pb}$ dating of detrital zircons. The temporal framework to interpret provenance data comes from surface exposure ages measured on boulders collected from this same area (Hagen, 1995; Mathieson et al., 2012; Kaplan et al., 2014).

\subsection{Particle size analysis}

Particle size analysis was performed on all 36 till samples. Approximately $15-100 \mathrm{~g}$ of sub-sampled sediment from each sample was freeze dried for 24 hours. The weight of the coarse fraction $(>1000 \mu \mathrm{m})$ was determined after dry sieving. Approximately $1-2 \mathrm{~g}$ of the fine fraction $(<1000 \mu \mathrm{m})$ was then heated for $1-1.5$ hours with $5 \mathrm{~mL}$ of $30 \% \mathrm{H}_{2} \mathrm{O}_{2}$ added every 30 minutes to remove organic material. The remaining $<1000 \mu \mathrm{m}$ fraction was dispersed in $20 \mathrm{~mL}$ of $2.5 \mathrm{~g} / \mathrm{L}$ sodium metaphosphate. Splits of the 1-2 gram samples were analyzed using a Malvern 
Mastersizer 2000 laser particle-size analyzer. Each sample was measured (percent by volume) 3-6 times for its $0.02-1000 \mu \mathrm{m}$ size distribution and the average of these values is reported.

\subsection{U-Pb analysis of detrital zircons}

In preparation for $\mathrm{U}-\mathrm{Pb}$ zircon analysis, the $63-150 \mu \mathrm{m}$ fraction of 8 till samples and 4 cobbles were sent to the Arizona LaserChron Center (ALC) where standard zircon separation and mounting procedures were followed (Gehrels, 2012). Low resolution back-scatter electron (BSE) images were used to differentiate the zircons from other minerals and to aid in avoiding inclusions, cracks, or regions of zonation that may produce unreliable ages.

The U-Pb isotopic ratio was measured for zircons from 8 till samples following the methods described in Gehrels et al. (2008) and Gehrels (2012). In most cases >100 grains were analyzed, but one sample (1A) had a low zircon yield. The R33 standard zircons were analyzed for calibration purposes at the beginning, middle, and end of each sample and are of known age of 419.3 \pm 0.4 Ma (Black et al., 2004). The Sri Lankan (SL) zircons are $563 \pm 2.3 \mathrm{Ma}$ in age and were analyzed and at the beginning and end of each sample, as well as after every fifth unknown zircon analysis to correct for elemental fractionation (Gehrels et al., 2006). This method of standard-sample bracketing yields accuracy of 1-2\% (2-sigma) (Gehrels, 2012). 
Table 1

Sample site information.

Till

\begin{tabular}{|c|c|c|c|c|c|c|}
\hline & SAL & Sample ID & Latitude & Longitude & $\begin{array}{l}\text { thickness } \\
(\mathrm{cm})\end{array}$ & Munsell color of dry till \\
\hline \multirow{10}{*}{ Tail } & 1948 & East Crest & -84.11096 & 162.16574 & $4-5$ & Greyish Brown \\
\hline & 1949 & $1 \mathrm{H}$ & -84.10696 & 162.05138 & --- & Grey \\
\hline & 1914 & $1 \mathrm{G}$ & -84.1076 & 162.05008 & 5 & Dark Grey \\
\hline & 1971 & 1G Red/Grey & -84.10816 & 162.05466 & --- & Dark Grey-Lt. Olive Grey \\
\hline & 1969 & 1F Crest 1 & -84.11539 & 161.90712 & 3 & Dark Grey \\
\hline & 1970 & 1F Crest 2 & -84.1157 & 161.90967 & 12 & Grey \\
\hline & 1913 & $1 \mathrm{E}$ & -84.13533 & 161.8172 & 2 & Dark Grey \\
\hline & 1951 & 1E Red/Grey & -84.13554 & 161.84344 & $4-5$ & Dark Grey-Very Dark Grey \\
\hline & 1968 & $1 \mathrm{D}$ & -84.16523 & 161.69415 & 1 & Light Grey \\
\hline & 1967 & $1 \mathrm{C}$ & -84.17773 & 161.53679 & $1-2$ & Light Grey \\
\hline \multirow{2}{*}{ Zone 1} & 1912 & $1 \mathrm{~A}$ & -84.1828 & 161.26768 & 3 & Dark Grey \\
\hline & 1952 & $1 \mathrm{~B}$ & --- & -- & 3 & Very Dark Grey \\
\hline \multirow{3}{*}{ Zone 2} & 1947 & $2 \mathrm{~A}$ & -84.1881 & 161.26773 & 8 & Light Grey-Light Olive Grey \\
\hline & -- & $2 \mathrm{~B}$ & -84.18681 & 161.24167 & 5 & Light Grey \\
\hline & -- & $2 \mathrm{C}$ & -84.18783 & 161.28987 & 4 & Light Brownish Grey \\
\hline \multirow{6}{*}{ Zone 3} & 1953 & $3 \mathrm{C}$ & -84.19074 & 161.28191 & $9-10$ & Light Grey-Light Olive Grey \\
\hline & 1916 & $3 \mathrm{D}$ & -84.19093 & 161.27972 & --- & Light Grey-Light Olive Grey \\
\hline & 1954 & 3 Dark & -84.19242 & 161.28790 & 8 & Dark Grey \\
\hline & 1941 & 3B & -84.19283 & 161. 28775 & 11 & Light Grey \\
\hline & 1915 & $3 \mathrm{~A}$ & -84.19307 & 161. 28751 & 12 & Light Grey \\
\hline & 1955 & $3 \mathrm{E}$ & -84.19486 & 161.27872 & 14 & Light Olive Grey \\
\hline \multirow{12}{*}{ Zone 4} & 1921 & $4 \mathrm{~L}$ & -84.2017 & 161.27872 & $>35$ & Light Olive Grey \\
\hline & 1943 & $4 \mathrm{~K}$ & -84.20215 & 161.33037 & $>30$ & Light Brownish Grey \\
\hline & 1920 & $4 \mathrm{~J}$ & -84.20238 & 161.32782 & $>18$ & Grey \\
\hline & 1960 & $4 \mathrm{I}$ & -84.20473 & 161.35077 & --- & Pale Yellow-Lt Yellowish Brn \\
\hline & 1959 & $4 \mathrm{G}$ & -84.20892 & 161.3671 & 34 & Pale Yellow-Lt Yellowish Brn \\
\hline & 1972 & $4 \mathrm{H}$ & -84.20918 & 161.36667 & $>22$ & Pale Yellow \\
\hline & 1919 & $4 \mathrm{~F}$ & -84.21372 & 161.36685 & --- & Light Yellowish Brown \\
\hline & 1958 & $4 \mathrm{E}$ & -84.21606 & 161.36421 & $>30$ & Light Yellowish Brown \\
\hline & 1957 & $4 \mathrm{D}$ & -84.21841 & 161.36061 & $>28$ & Pale Yellow \\
\hline & 1918 & $4 \mathrm{C}$ & -84.21909 & 161.36067 & $>30$ & Pale Yellow \\
\hline & 1942 & $4 \mathrm{~B}$ & -84.22171 & 161.35822 & $>30$ & Pale Yellow \\
\hline & 1917 & $4 \mathrm{~A}$ & -84.22298 & 161.35559 & $>45$ & Pale Yellow \\
\hline \multirow{5}{*}{ Zone 5} & 1922 & $5 \mathrm{~A}$ & -84.22598 & 161.27373 & $>15$ & Pale Yellow-Lt Yellowish Brn \\
\hline & 1923 & $5 \mathrm{~B}$ & -84.22861 & 161.27284 & $>15$ & Pale Yellow-Lt Yellowish Brn \\
\hline & 1962 & $5 \mathrm{C}$ & -84.23213 & 161.27444 & -- & Pale Yellow-Lt Yellowish Brn \\
\hline & 1924 & $5 \mathrm{D}$ & -84.23618 & 161.28149 & --- & Greyish Brown \\
\hline & 1963 & $5 \mathrm{E}$ & -84.22989 & 161.30516 & --- & Pale Yellow-Lt Yellowish Brn \\
\hline
\end{tabular}


Using laser ablation multicollector inductively coupled plasma mass spectrometry (LAMC-ICPMS), analysis of zircons was completed utilizing a Photon Machines Analyte G2 Excimer laser that ablates a pit $30 \mu \mathrm{m}$ in diameter and $\sim 15 \mu \mathrm{m}$ deep. Data collection for each zircon consisted of measuring one 15-second integration for background with the laser off, 15 one-second integrations with the laser firing, and finally a 30 second delay to purge the previous sample and prepare for the next analysis. The ablated material was carried in helium gas into the plasma source of the Nu Plasma HR ICPMS. These measurements were collected using $3 \times 10^{11}$ ohm Faraday detectors for ${ }^{238} \mathrm{U},{ }^{232} \mathrm{Th},{ }^{208} \mathrm{~Pb}$, and ${ }^{206} \mathrm{~Pb}$, a $10{ }^{12}$ ohm Faraday collector for ${ }^{207} \mathrm{~Pb}$, and dynode ion-counting channels for ${ }^{204} \mathrm{~Pb}$ and ${ }^{202} \mathrm{Hg}$. Ion yields are $\sim 0.8 \mathrm{mv}$ per ppm (Gehrels et al., 2008).

Interpreted ages are based on ${ }^{206} \mathrm{~Pb} /{ }^{238} \mathrm{U}$ for grains $<1.0 \mathrm{Ga}$ and on ${ }^{206} \mathrm{~Pb} /{ }^{207} \mathrm{~Pb}$ for grains $>1.0 \mathrm{Ga}$ (Gehrels et al., 2008). Ages $>30 \%$ discordant or $>5 \%$ reverse discordant were excluded from analyses. For most detrital zircon samples, significant age populations are only defined as clusters with three or more overlapping analyses (Gehrels, 2012). The resulting ages are shown on relative age probability diagrams using the routines in Isoplot (Ludwig, 2003). The U-Pb ages were also analyzed using the Kolmogorov-Smirnov test (K-S test) in order to evaluate the goodness-of-fit between distributions.

\section{Results}

\subsection{Field Observations}

A defining feature of the MAM is a series of troughs and ridges 1-12 meters high that have formed roughly parallel to the Law Glacier margin (Fig. 1). Distinct colored bands parallel the ice-moraine boundary and are related to the dominant pebble/cobble lithology (Fig. 3). The geomorphology and color was the basis for separating the moraine into multiple distinct regions, or zones, that are used throughout this study. Zone 1 has hummocky topography, some frozen 
meltponds, widespread moist till and a gray hue with rocks displaying little surficial weathering, and some sporadic salt crusts. Zone 2 is relatively flat in the area of the transect, lacks distinct color changes, and contains a much lower abundance of boulders and cobbles on the moraine surface compared to the other zones. This is consistent with prior observations by Faure et al. (1992). Zone 2 pinches out toward the tail region of the moraine. Zones 3 and 4 both have welldefined parallel/sub-parallel ridges superimposed on different background topographic trends (Fig. 5), as well as distinct differences in color and dominant debris composition. Zone 3 is dominated by sedimentary rocks and, in the middle of the MAM, has the overall relief of a broad arch, with an $\sim 18$ m elevation increase from the Zone $2 / 3$ boundary to the highest point and the same $\sim 18 \mathrm{~m}$ elevation drop at the Zone $3 / 4$ boundary (Fig. 5). A lateral moraine occurs along the base of Mt. Achernar and extends from the ice margin to the Zone 3/4 boundary (Fig. 1). Zone 4 has distinct color and compositional bands that alternate between dominant sedimentary and mafic igneous rock types. This zone exhibits an overall steady elevation increase of $\sim 30 \mathrm{~m}$ up and away from Law Glacier (Fig. 5).

Eastward, away from the transect, toward the tail, the ridge/trough topography of Zone 4 is distorted by the Lewis Cliff Ice Tongue impinging on the moraine from the south (Fig. 1). Zone 5 is characterized by extensive varnish on the cobbles and boulders, topography sloping up to the southeast, and parallel/sub-parallel ridges indicating input from an unnamed ice tongue flowing down over Lewis Cliff (Fig. 4).

In the area of the tail along the Law Glacier, the moraine characteristics are the same as Zone 1 , however the inner margin of Zone 1 is marked by a snow-covered gap $(<20 \mathrm{~m}$ wide $)$ followed by a $\sim 90^{\circ}$ change in orientation of topographic ridges/troughs so that they are perpendicular to zone 1. Here, rocks exhibit dark red varnish associated with more extensive weathering of the Ferrar dolerite (i.e., Mercer, 1968) marking a temporal discontinuity. 
$\mathrm{A}{ }^{10} \mathrm{Be}_{-}{ }^{26} \mathrm{Al}-{ }^{3} \mathrm{He}$ exposure chronology of the MAM was previously reported from samples collected along the main provenance transect (Figs. 4 and 5) (Mathieson et al., 2012; Kaplan et al., 2014). Samples in Zone 1 date to the Holocene (Marine Isotope Stage (MIS) 1), ages in Zones 2 and 3 span the last glacial cycle ( 10-50 ka, MIS 1-3), and Zone 4 ages are on the $10^{5}$ timescale, extending through at least MIS 5-6 and possibly exposure as old as MIS 13-14. The chronology fits well our observations of rock weathering and a small previously obtained dataset from Hagen (1995). Zone 1 rocks, in particular, are fresh with little evidence of weathered surfaces and whereas rocks become increasingly coated in a dark red varnish from Zones 2 through 4 .

\subsection{Particle Size}

Overall, tills of the MAM consist of $~ 20-30 \%$ gravel, 30-45\% sand, and 30-40\% silt and clay. Particle size distribution data, averaged by zone, show an overall pattern of increasing sand and decreasing silt and clay with increasing distance from the active ice margin (Fig. 6, Supplementary Table 2). Despite the trend, Zones 1 and 4 and the tail have a wide range of variability and sample $4 \mathrm{~F}$ is an outlier with extremely low sand and high silt and clay content.

\subsection{Pebbles}

The pebble lithology data along the transect show distinct changes in dominant rock type between and within zones (Fig. 7, Supplementary Table 3). Zones 2 and 3 are distinct with twice as many sedimentary rocks compared to other zones. Within Zone 4 , the abundance of sedimentary and igneous rock fragments, primarily sandstone and dolerite, varies up to 70\% between adjacent crests (i.e., 4A and 4B), consistent with field observations of distinct lithologic bands (Fig. 3C). Both locally exposed and exotic rock type are found. Most rocks are similar in appearance to rocks from the Ferrar and Beacon Supergroups, specifically the Buckley, Fairchild, and Mackellar Formations from the Beacon Supergroup. Only $<2 \%$ of pebbles are 
felsic igneous and metamorphic rocks, with the majority of the metamorphic pebbles categorized as quartzite; these likely formed from contact metamorphism of the Beacon sedimentary rocks.

The observations of lithologic change are supported by cluster analysis of the pebble lithologic data, which delineated three main clusters (Suppl. Fig. 2). Cluster A consists of all samples from Zone 3 and sample 4C, all having a dominant sandstone component. Cluster B consists of samples from Zones 1, 4 and 5 which are all dominated by mafic/intermediate igneous rock types. Samples 4A and 5A are outliers; 4A is rich in metamorphosed sandstone and 5A contains abundant chert. Cluster $\mathrm{C}$ contains only samples from Zone 2, which is dominated by siltstone and metasiltstone.

\subsection{U-Pb analysis of detrital zircons}

\subsubsection{Bulk till}

In total, 830 zircons from the till samples produced concordant ages that were used for interpretations (Fig. 8; Supplementary Table 4). The zircon ages in the till range from Triassic to Archean ( 205-3495 Ma) and there are common populations in the Proterozoic 565-600 Ma, and $~ 950-1270 \mathrm{Ma}$, as well as the late Archean $\sim 2670-2730 \mathrm{Ma}$ (Fig. 8a). Very small (n=2 to 5 ages), but consistent populations of grains are 250-270 Ma and 2270-2320 Ma. The zircon age distributions show little variation across the moraine and the Neoproterozoic population is dominant across all till samples. Sample sites 4J and 4L show a 40 Ma change to younger ages in the Neoproterozoic Ross/Pan-African population. K-S test results of the detrital zircons reveal that sites $4 \mathrm{~J}$ and $4 \mathrm{~L}$ provide the only two samples that are not statistically similar to other sampled tills across the transect (Supplementary Table 5).

\subsubsection{Cobbles}

Cobbles representing dominant sedimentary rock types observed on the moraines were analyzed to determine $\mathrm{U}-\mathrm{Pb}$ signatures of potential sources of MAM till. Z3B-1, collected from 
Zone 3, is visually similar to sandstones of the Mackellar Formation and 0Z5-1, collected from Zone 5, is consistent with the Pagoda tillite. The U-Pb detrital zircon age population for both cobbles ranges from early Cambrian to late Archean, with the dominant peak in the Neoproterozoic 580-600 Ma (Fig. 8b; Supplementary Table 4). A second dominant Mesoproterozoic population ( 1190 Ma) is most pronounced in the tillite.

Z5c/d-1 and Z5c/d-2 are granite and granitoid cobbles collected between sample sites 5C and 5D. $100 \%$ of the age population ( $n=13$ and 28 respectively, or $n=20$ and 46 if both the core and rim measurements are included) for both cobbles lies within the Mesoproterozoic between 1400-1480 Ma (Supplementary Table 4). Grains of this same age are also present, though very low abundance, in the Permian tillite cobble (0Z5-1) and in till sites $2 \mathrm{~A}, 3 \mathrm{~B}, 4 \mathrm{~K}, 4 \mathrm{~L}$, and 4B $(n=11)$.

\section{Discussion}

The provenance data collected from the MAM provides critical information for assessing ice sheet changes and potential debris source variability over time, as well as an opportunity to compare results from different methods used. We hypothesize if the EAIS remained a constant thickness with no change in the catchment area over glacial/interglacial cycles, that the MAM would have been fed by a consistent debris source, whereas an ice sheet with variable thickness or change in catchment boundaries and/or flow path could result in a shift in debris sources that would be reflected in the moraine's till composition.

\subsection{Lithologic sources of the till}

The material exposed in blue-ice moraines is interpreted to originate predominantly from mechanical erosion of subglacial bedrock along the path of glacial drainage. In the case of East Antarctic outlet glaciers, a large area may be eroded and the composition of the till reflects the integrated bedrock composition in the glaciated catchment, with a bias toward proximal bedrock 
rather than rock types from the catchment head. Pebble and cobble lithologic data reveal that the composition of the MAM till is consistent with locally-exposed bedrock (Buckley and Ferrar), but also has a significant non-local (exotic) component, whose abundance varies spatially. Pebbles from the MAM transect and tail together average 56\% igneous, 3\% metamorphic, and $41 \%$ sedimentary. On average $20 \%$ of the pebbles on the moraine surface are faceted and/or striated, providing clear evidence for active subglacial erosive processes.

Most of these rocks of the MAM are interpreted to derive from the Jurassic Ferrar Supergroup and the Mackellar, Fairchild, and Buckley Formations of the Beacon Supergroup. Because the bedrock elevation decreases upstream from Mt. Achernar (Fretwell et al., 2012) it is likely that Beacon units stratigraphically below the Buckley Formation occur upstream in the catchment and are being eroded by the Law Glacier. The absence of Nimrod Group and Granite Harbor Intrusive rocks in the MAM till suggest that these units do not extend into the Law Glacier catchment. In Zone 5, a greater degree of compositional variability is observed in the cobble fraction relative to zones 1-4. Erratics that were identified in the non-random cobble collection from Zone 5 include granite, granitoid/gneiss, granodiorite, quartzite, conglomerate, diamictite, chert, marble, and coral, none of which are exposed upstream of Mt. Achernar and the UNIT.

\subsubsection{Distinct Zones}

Cluster analysis of pebble lithology indicates that Zones 2 and 3 are the most distinguishable of the zones along the transect, with each of these Zones clustering in their own group (Suppl. Fig. 2). Zones 2 and 3 are dominated by sedimentary rocks whereas the dominant lithology for the other zones and the tail are intermediate/mafic igneous (Ferrar dolerite) (Fig. 7). Although sandstone and meta-sandstones dominate the lithology in Zone 3, it was noted during collection that mudstones would be underrepresented in Zone 3 pebble analysis because they 
easily broke into thin sheets and were unable to be collected intact.

In the southeastern part of the field area, geomorphic evidence suggests that Zone 5 till is derived from a different source than the rest of the MAM. Whereas the debris in Zones $1-4$ and the tail are delivered by Law Glacier, the orientation of ridge crests in Zone 5 indicates that this area is fed by the unnamed ice tongue (UNIT) shown in Figure 4. Although the U-Pb ages of detrital zircons are very similar to the other zones, we note that Zone 5 is unusual in its number of grains 490-550 Ma (Fig. 8a). Overall, the pebble types in Zone 5 are indistinguishable from Zones 1, 4 and the tail, but the cobbles collected in the non-random survey have a higher fraction of exotic rock types (i.e., granite, gneiss). As noted in section 2, the bedrock walls adjacent to Zone 5 are the only place where Pagoda, Mackellar, and Fairchild Formations are exposed in fault slices on the east facing wall (Elliot, personal comm.) and relatively abundant Cambrian Shackleton limestone and Douglas conglomerate (pre-Beacon rocks) float occur on the west facing hillside.

The granite (Z5 c/d-1) and deformed granitoid (Z5 c/d-2) collected are unique to Zone 5. $\mathrm{U}-\mathrm{Pb}$ zircon ages from these two erratics show a narrow range $~ 1400-1480 \mathrm{Ma}$ (Supplementary Table 4). Geochemical, isotopic and petrographic analyses were conducted on both Z5 c/d-1 and 2 and were found to be indistinguishable from Laurentian granites and a granite erratic from the Nimrod Glacier (TNQ) (Hodgson et al., 2013). The source of these Rodinian-aged cobbles is not exposed in the TAM and the granite and granitoid cobbles are interpreted to have an origin associated with that of sample TNQ reported in Goodge et al. (2008). Notably, detrital zircon grains of this age are absent in the Zone 5 till sample analyzed, but present in other sites across the transect (Fig. 8a). One explanation for the presence of the $\sim 1400-1480$ Ma grains, but lack of granite/granitoid cobbles in the Zones 1-4 till is that this population of grains is derived from the Pagoda Formation (Elliot et al., 2014). The Pagoda tillite is the only other rock sample that 
has a 1400-1480 Ma population of zircons (Supplementary 4). Another possible explanation is that the Law Glacier catchment area is eroding into this igneous source, but pebbles and/or cobbles of this igneous suite were simply missed and not collected; this is unlikely given that $\sim 5 \mathrm{x}$ more time was spent working in Zones 1-4 than Zone 5. Therefore, these Rodinian-aged cobbles either originated as clasts within the Pagoda tillite or an igneous suite of very limited spatial extent buried upstream of the unnamed ice tongue, but not upstream of the MAM.

\subsection{Evaluating rockfall vs glacially transported debris}

Scarrow et al. (2014) studied soil development of the MAM and noted that lower horizons in the MAM were consistently darker, finer grained, and higher in carbon content than the overlying material. Consistent with their observations, we found that dark grey till was overlain by a $2 \mathrm{~cm}$ buff-colored layer that was particularly well developed in Zone 3 . Scarrow et al. (2014) interpreted these characteristics as an indication for different sources for the two soil layers: the uppermost layer deriving from supraglacial debris degraded by weathering, and the bottommost till being fed into the moraine by a subglacial source. The provenance dataset allows us to evaluate this assertion.

Some blue ice moraines around Antarctic nunataks are covered in coarse, blocky debris that is compositionally identical to the wall rocks, whereas others have an abundance of fines and exotic rock types as well as numerous faceted/striated pebbles and cobbles (i.e., Hättestrand and Johansen, 2005; Palmer et al., 2012; Licht and Palmer 2013). Rockfall from Mt. Achernar and the MacAlpine Hills probably contributes some debris along the Law Glacier margin, however, subsurface-derived debris bands emerging parallel along the length of the active ice at the moraine edge (Fig. 3) are the dominant supply of till accumulating in the moraine. Many sedimentary rock types that are common in the moraine are not consistent with descriptions of the exposed Buckley Formation (Isbell, 1990) and $20 \%$ of pebbles collected from the moraine 
surface are faceted and/or striated. These two lines of evidence indicate that en- and subglacially transported material is the dominant source of the debris on the surface of the moraine. A source of supraglacial debris that would supply the diversity of material to the entire moraine area and produce the distinct lithologic bands is lacking (Fig. 3C).

The origin of the non-faceted/striated pebbles $(\sim 80 \%)$ may be explained in several ways. It seems likely that debris entrained as ice passes over large- and small-scale variations in bed topography becomes englacial where rock-rock contact would be minimal. Alternatively, the debris could originate from and be transported along the bed slowly by cold-based ice. In either case, without additional information about the bedrock composition, the transport distances cannot be determined from the current dataset. As noted above, we cannot totally discount rockfall as a source of some debris to the MAM, but in addition to limited rockfall on the moraine, we observed very little evidence of rockfall on the blue-ice surface adjacent to Mt Achernar, therefore we conclude this that must be a very minor component. Based on our provenance work, we suggest that debris in both the upper and lower horizons of the MAM till was delivered primarily by en- and/or subglacial processes, and that the weathering of surface debris observed by Scarrow et al. (2014) may produce an apparent provenance change with depth.

\subsection{Evolution of the Mt. Achernar Moraine}

Based on field observations, provenance data, and concepts from the blue-ice moraine literature (i.e., Chinn, 1991; Cassidy et al., 1992), we have developed a conceptual model for the formation of the MAM. Our model may be applicable to other such moraines elsewhere around Antarctica in similar settings. As the debris bands emerge with subglacially-derived material, sediment becomes concentrated on the ice surface through sublimation while till thickness 
increases. Scarrow et al. (2014) calculated that $50 \mathrm{~cm}$ of debris accumulation may develop in as little as 300,000 years.

In the case of the MAM, the clear variations in the composition of pebble to boulder size fractions of the till indicate a change in the debris source to the moraine. We think these source changes can best be explained by linking the local bedrock stratigraphy to the till accumulation patterns at MAM. The progression of lithologic changes across the moraine appears to represent a reversed underlying bedrock stratigraphy. The oldest glacial deposits in Zone 4 reflect subglacial erosion into the Buckley Formation and Ferrar dolerite, with zircons indicating some input from the Fairchild Formation. The color bands within Zone 4 are notable in their sharp, distinct compositional boundaries, suggesting little mixing and stability in the debris transport process. Subsequently, as the moraine continued to accumulate debris (progressively closer to the present Law Glacier margin), the ice delivered debris from successively lower stratigraphic units of the Beacon Supergroup (Fig. 9). The vast majority of Zone 2 pebbles are greywackes or siltstones, consistent with derivation from the Mackellar Formation or possibly the lowermost Buckley. We infer that many of the faceted and striated rock fragments were abraded or eroded in place and then plucked by overriding ice of the relatively fast flowing Law Glacier. The overall pattern of reversed bedrock stratigraphy in the moraine sediments suggests that subglacially entrained debris is delivered from progressively lower formations of the Beacon Supergroup, which could reflect deepening of the Law Glacier trough if erosion rates were exceedingly high, or more likely, bedrock topographic controls on the debris delivery pathways as the source of emerging debris bands shifts toward deeper parts of the trough.

To place the provenance changes discussed above in the context of Law Glacier and East Antarctic ice sheet behavior, we consider geomorphic observations and the surface exposure age data from this site (Mathieson et al., 2012; Kaplan et al., 2014). Surface exposure ages indicate 
that Zone 4 records till accumulation during MIS 5 and 6 and perhaps as far back as $\sim$ MIS 1314. In either case, this means that the MAM existed during the MIS 5 interglacial. The sharp, quasi-continuous compositional bands and ridge/trough morphology of Zone 4 (Fig. 3) indicate relative stability of the MAM system across Stage 5 as such features would likely not have been preserved if there were a significant thinning and interruption of ice flow associated with Law Glacier surface lowering during MIS 5.

A lateral moraine at the base of Mt. Achernar indicates that ice was $<40 \mathrm{~m}$ thicker in the past (Fig. 10). In the field, we traced on foot the intersection of this lateral moraine and the larger MAM to the boundary between Zones 3 and 4. Surface exposure ages of boulders along the same transect reveal that the time represented at the Zone 3/4 boundary is $\sim 50 \mathrm{ka}$ (Mathieson et al., 2012; Kaplan et al., 2014) (Fig. 5). The geomorphology of Zone 3, the broad arch feature (Fig. 5) rising $\sim 18 \mathrm{~m}$ above the moraine surface with superimposed smaller ridges, may either be a result of compression from more ice flowing into the moraine during the LGM, or ice sheet thickening where the arch is a remnant of thicker ice from the LGM. We infer that the thicker ice existed when Law/Lennox-King Glacier system was dammed by grounded ice in the Ross Sea. We speculate that the absence of distinct, parallel topographic ridges in Zone 2 represents deglaciation; a period in which there was less ice input into the moraine and the ridges were not formed and/or preserved. At the very least, Zone 2 does not appear to represent a period of increased flow into the MAM.

The youngest section of the moraine, Zone 1, is the region of the moraine where till is thinnest and therefore experiencing the highest sublimation rates and highest till accumulation rates. Surface exposure ages from this zone are Holocene in age (Mathieson et al., 2012; Kaplan et al., 2014). We attribute the hummocky morphology of Zone 1 to differential ablation causing topographic inversions. This is related to minimal till thickness $(1-3 \mathrm{~cm})$ and the low albedo of 
the till (grey-very dark grey) leading to uneven sublimation and even some minimal melting; melt ponds and liquid water were observed during field investigations in 2011 and 2015.

In sum, the discrete changes in till provenance, when set in the temporal context provided by surface exposure ages, indicate relative stability of the East Antarctic ice sheet from MIS 6 through the present. Significant thinning of the outlet glaciers draining from the East Antarctic interior through the Transantarctic Mountains during a major deglaciation event in the Ross Embayment during MIS 6 would have caused glacial debris to be drawn away from the moraine as the ice thinned (Fogwill et al., 2012) and therefore would not have preserved the ridges (i.e., Zone 2) and discrete compositional bands in Zone 4.

\subsection{Analysis of provenance methodologies}

Pebble lithology and $\mathrm{U}-\mathrm{Pb}$ data from detrital zircons are both common provenance tools used to identify past ice flow pathways. Unique zircon populations associated with upstream rock units, or even significant missing populations have been successfully used as a tracer to determine the source of ice from TAM outlet glaciers and WAIS ice streams flowing into the Ross Sea (e.g., Licht and Palmer, 2013; Licht et al., 2014). Likewise, lithologic studies of pebble fractions have been successfully utilized to determine the extent of both the local and subglacial input of ice and debris flowing into moraines (e.g., Palmer et al., 2012). However, this study reveals that significant information regarding changes in provenance can be missed by some provenance tools, depending on the local and regional bedrock composition. The U-Pb data for the MAM tills reveals little change across the moraine (Fig. 8a), indicating the same provenance over time, but as discussed in section 5.1, pebble lithologic data indicate this is not the case. The lithologic data of the pebble fraction proves to be a vital source of information regarding a change in provenance at the heads of outlet glaciers, whereas pebble studies further downstream on the continental shelf are more challenging because offshore cores are too small to get 
statistically representative samples of pebbles from narrow time intervals.

Several factors must be considered when interpreting the results from the $\mathrm{U}-\mathrm{Pb}$ analysis of not only detrital zircons in the MAM, but many other moraines in Antarctica where there is a broadly similar rock record. U-Pb analysis provides the age of crystallization or metamorphic overgrowth of a zircon grain, but often not the complete history of the zircon, nor the age of the deposit it is in. Zircon is very resistant to weathering so it has the potential to be eroded from a host rock and be deposited, or recycled into younger sedimentary rock units, potentially multiple times. Therefore determining the origin of detrital zircons from till can be particularly challenging, especially where potential bedrock sources are covered by ice.

The local felsic igneous rocks that crop out in the TAM are a potential source of zircon populations in till. Zircons from Granite Harbour Intrusives from the central TAM are $~ 480-545$ Ma (Goodge et al., 2012; Paulsen et al., 2013), however, this was not the dominant population in MAM tills. Therefore it is unlikely that zircons 550-600 Ma in till were derived from a primary igneous source. U-Pb ages of 550-600 Ma are ubiquitous in tills across the TAM (Licht et al., 2014), including from the MAM. Sedimentary rocks of the Pagoda, Fairchild and Mackellar Formation reveal similar age distributions as found in the till, with abundant zircons $\sim 550-600$ Ma (Fig. 8b) (this study; Elliot and Fanning, 2008; Elliot et al., 2014). Bedrock samples from the Pagoda and Fairchild Formations contain a much smaller proportion of grains 500-550 Ma compared to 550-600 Ma grains. Although the lower Buckley sample contains zircons 550-600 Ma, it has many more grains 500-550 Ma, indicating that it cannot be the dominant source of zircons to MAM till. Rocks of the upper Buckley have very few grains 500-600 Ma, and instead are dominated by a Permian-early Triassic population (245-260 Ma). The only MAM till that contains a significant population of these young zircons (>2 grains) is sample 4J (Fig. 8a) leading 
us to conclude that the upper Buckley and Fremouw Formations provide little sediment input to most MAM till.

The U-Pb zircon data can be helpful in refining the debris sources to the moraine and complement data from the pebble fraction. The dominance of grains 550-600 Ma suggest that Pagoda, Mackellar, Fairchild and lower Buckley and Fremouw Formations are all possible contributors to the fine sand fraction (zircon sizes) of the till at the MAM and potentially along much of the southern-central Transantarctic Mountains given observations by Licht et al. (2014). Although the Pagoda has abundant zircons in the 550-600 Ma range, it is not observed in high abundance in the pebble fraction. The Fremouw Formation contains both abundant Permianearly Triassic and 550-600 Ma, grains. If this were a dominant input, we would expect to find more Permian-early Triassic grains. Thus, the data indicate that the Mackellar, Fairchild and lower Buckley are the most likely sources. U-Pb zircon ages at sites $4 \mathrm{~L}$ and $4 \mathrm{~J}$ have a $40 \mathrm{Ma}$ shift in the dominant Ross/Pan-African population, with peaks $\sim 550$ and $\sim 555 \mathrm{Ma}$ (Fig. 8a), this peak is most clearly seen in the Fairchild Formation, which occurs between the Buckley and Mackellar Formations and is consistent with our conceptual model of progressive erosion through the sedimentary sequence of the Beacon Supergroup. Although granitic rocks of the Granite Harbour Intrusives and/or like the erratic granite (KTW) collected at Kon-Tiki nunatak (Goodge, 2012) were not found in the MAM, it cannot be ruled out that a few grains from these sources are being subglacially eroded, englacially transported, and deposited in the MAM as well.

\section{Summary and Conclusions}

The blue ice moraine adjacent to Mt. Achernar serves as an important archive of Law Glacier flow history that is revealed by analysis of till composition, moraine geomorphology, and relief. Furthermore, the moraine composition provides evidence for the rock units that are 
buried by the Law Glacier and EAIS that are otherwise not directly observable, and which are essential to explaining provenance changes over time.

Overall, the moraine debris consists of both locally-outcropping and unexposed bedrock material that is mostly derived from the Beacon and Ferrar Supergroups and, in places, shows distinct color changes that are directly related to the dominant lithology of the till. The presence of alternating lithologic bands, distinct differences in morphology, and relative weathering patterns across the MAM moraine help distinguish separate "zones" within the moraine. Zone 4 consists of alternating bands of weathered Ferrar and Beacon rocks. It is interpreted to represent pre-LGM till accumulation of Ferrar and Buckley Formation rocks transported en- and subglacially to the moraine surface. The lateral moraine intersecting the Zone 3/4 border, Zone 3 surface exposure ages ranging from 12-50 ka (Mathieson et al., 2012; Kaplan et al., 2014), and the distinct geomorphology of a broad arch, all support a model in which Zone 3 records a time of ice sheet thickening and a provenance change (Ferrar dolerite abundance declines significantly) beginning in MIS 3, the earliest phase of the LGM. Zone 2 contains sediment primarily derived from Mackellar Formation and provides a record of deglaciation. Zone 1 is still actively connected to the Law Glacier and still accumulating debris.

In contrast to the pebble lithologic data, $\mathrm{U}-\mathrm{Pb}$ zircon ages indicate that the debris source to the MAM has been relatively consistent throughout its history. U-Pb ages of detrital zircons collected from MAM till and sandstone cobbles reveal that the dominant zircon populations are consistent with a Beacon source that is not locally exposed (most similar to the Mackellar and Fairchild Formations). The apparent contradiction between a consistent supply of sediment implied by the U-Pb zircon data and provenance change indicated by the pebbles can be explained by the absence of zircons in the local outcrops of Ferrar dolerite, making it 'invisible' in $\mathrm{U}-\mathrm{Pb}$ zircon analysis. 
This study reveals the value of detailed provenance analysis of Antarctic tills and that using multiple analytical techniques can be essential when interpreting till provenance. At the MAM, all provenance tools are needed to recognize that the progression of lithologic changes across the moraine represents reversed underlying bedrock stratigraphy of the Law Glacier; that is, provenance changes can be explained solely by Law Glacier tapping into successively lower stratigraphic units of the Beacon Supergroup, rather than indicating significant changes within East Antarctic ice sheet catchment boundaries. This has important implications for interpreting long temporal record from cores, such as ANDRILL. For instance, provenance analysis of a core collected downstream of an outlet glacier, such as the Law/Lennox-King Glacier system, may show a shift in provenance that could erroneously be interpreted as a flow direction change when it actually reflects progressive erosion into deeper bedrock layers.

\section{Acknowledgements}

This research was supported by the National Science Foundation Office of Polar Programs grant NSF-0944578 and NSF-0944475 and IUPUI Educational Enhancement and School of Science Graduate Student Council Grants. We appreciate constructive comments by D. Sugden and an anonymous reviewer. We thank R.J. Swope, T. Flood, T. Dits, B. Welke, J. Graly, J. Isbell, D. Elliot, J. Schaefer, M.J. Parker, and S. Black for helpful suggestions and discussions. Thank you also to the University of Arizona Laserchron Center for assistance with U-Pb analyses, A. Grunow at the Polar Rock Repository, the Polar Geospatial Center, and the United States Antarctic Program and mountaineer Mike Roberts for fieldwork support. 


\section{Figure Captions}

Figure 1. Study area in the central Transantarctic Mountains. A) regional map highlighting the location of Mt. Achernar at the inland margin of the TAM where flow transitions from unconstrained East Antarctic Ice Sheet (EAIS) flow into the Law Glacier. B) Mt. Achernar moraine where primary sediment input is from the Law Glacier; dashed line indicates location a lateral moraine at the base of Mt. Achernar. Two ice tongues (MA - Mt. Achernar, UNIT unnamed ice tongue and LCIT - Lewis Cliff ice tongue) impinge on the southern margin of the moraine. C) Numbered zone boundaries highlight geomorphic transition from hummocky topography near Law Glacier (zone 1) to well-developed parallel ridges/troughs in zone 4. Zone 5 ridges curve toward the south showing sediment input from the unnamed ice tongue. Imagery from DigitalGlobe provide by the PGC.

Figure 2. Simplified stratigraphic column of the Beacon Supergroup from the central Transantarctic Mountains along with dominant detrital zircon (DZ) age peaks from this study* and Elliot and Fanning, 2008 and Elliot et al., 2014. See Supplementary Figure 1 for complete zircon age distributions. (Modified from Elliot et al., 2014.)

Figure 3. Conceptual model of the setting of the Mt. Achernar moraine (gray shaded area) adjacent to Law Glacier draining the East Antarctic Ice Sheet (B). Photos from the site highlight numerous emerging debris bands at the edge of the moraine (A) and distinctly-colored debris bands in zone $4(\mathrm{C})$.

Figure 4. Mt. Achernar moraine with topographic profile transect (shown in Figure 5) delineated by a red line and sample locations shown by dots (colored by zone). Zone 1 samples are along this transect as well as downstream along the debris/ice boundary (the 'tail'). Note that zone 5 samples are sourced by the UNIT rather than Law Glacier. Gray arrows indicate ice flow direction. Blue ice of the Law Glacier is the primary source of debris to the moraine. Two ice tongues impinge locally on the moraine; UNIT $=$ unnamed ice tongue and LCIT $=$ Lewis Cliff Ice Tongue. Imagery from DigitalGlobe provide by the PGC.

Figure 5. Topographic profile from the Law Glacier (left) across the Mt. Achernar moraine by a differentially processed Trimble Rover GPS system (see Fig. 4 for transect location). Zone 2 shows the least relief and Zone 3 has a broad 15+ $\mathrm{m}$ arch with superimposed ridges. Increasing till thickness is shown schematically and ranges from $<1$ to $>50 \mathrm{~cm}$ thick. Be-Al-He ages* are from Mathieson et al. (2012) and Kaplan et al. (2014).

Figure 6 . Box plots of $<2 \mathrm{~mm}$ particle size data by zone (Table 2 ). The box outlines the middle $50 \%$ of data ( $2^{\text {nd }}$ and $3^{\text {rd }}$ quartiles), the line inside the box represents the median value of the whole data set, and the whiskers show the greatest/least values excluding the outliers, which are defined as data that is greater than 1.5 times the box height. Zone 2 is not included in box plots because only one sample was collected. Dashed line separates tail samples from main transect samples. Tail $n=10$, Zone 1 along transect $n=2$, Zone $3 n=6$, Zone $4 n=12$, Zone $5 n=5$.

Figure 7. Pebble compositions of the Mt. Achernar moraine by zone and sample. a) Percent lithology by zone emphasizing relatively low abundance of Ferrar dolerite (igneous) rocks in zones 2 and 3; b) Percentage of pebble types present in each sample from the tail and transect, 
including proportion faceted and/or striated. Each sample reflects rocks collected from $1 \mathrm{~m}^{2}$. See Supplementary Table 1 for the classification scheme used to categorize pebbles.

Figure 8a. Normalized probability plots and histograms of Mt. Achernar moraine tills; sample names are on the right. Known geologic events and ages of interest are highlighted in gray (see Section 2). Figure 8b. Pie diagrams comparing samples of potential sources from Beacon Supergroup bedrock (left two columns) with MAM till (on the right). The age groups highlight the proportion of grains in zircon age groups with particular provenance significance. Some bedrock samples* are from Elliot and Fanning, 2008 or Elliot et al., 2014 and other bedrock samples and till samples are from this study. The Achernar till populations are most similar to the Fairchild, Mackellar and Pagoda Formations and least similar to the Buckley Formation, which is the locally outcropping bedrock.

Figure 9. Conceptual model of the formation of the Mt. Achernar Moraine showing the exposed $800 \mathrm{~m}$ thick bedrock section (Faure and Mensing, 2010) and inferred (ice-covered) bedrock stratigraphy along with the measured moraine topographic profile (Fig. 5). Dark horizontal bands represent Ferrar dolerite sills, three of which are exposed. Black arrows show hypothesized debris transport pathways that explain the source of compositional changes in till across the moraine This model highlights the sub- and englacial origin of the moraine sediment and spatiotemporal shift to debris sources lower in the bedrock stratigraphic section as new till accumulated toward what is the present day Law Glacier margin.

Figure 10. Photograph of lateral moraine created by Law Glacier at the base of Mt. Achernar. White dashed line highlights the MAM surface. 


\section{References Cited}

Ackert Jr., R.P., Mukhopadhyay, S., Pollard, D., DeConto, R.M., Putnam, A.E., Borns, H.W., 2011. West Antarctic Ice Sheet elevations in the Ohio Range: geologic constraints and ice sheet modeling prior to the last highstand. Earth Planetary Science Letters 307, 83-93.

Ackert Jr., R.P., Putnam, A.E., Mukhopadhyay, S., Pollard, D., DeConto, R.M., Kurz, M.D., Borns, H.W., 2013. Controls on interior West Antarctic Ice Sheet Elevations: inferences from geologic constraints and ice sheet modeling. Quaternary Science Reviews 65, 26-38.

Barrett, P.J., 1991. The Devonian to Jurassic Beacon Supergroup of the Transantarctic Mountains and correlatives in other parts of Antarctica. In: Tingey, R.J. (Ed.), The Geology of Antarctica. Oxford University Press, New York, pp. 120-152.

Barrett, P.J., Elliot, D.H., 1973. Reconnaissance geologic map of the Buckley Island Quadrangle, Transantarctic Mountains, Antarctica. U.S. Geological Survey, Antarctic Geologic Map A-3.

Bernet M., Gaupp, R., 2005. Diagenetic history of Triassic sandstone from the Beacon Supergroup in central Victoria Land, Antarctica. New Zealand Journal of Geology and Geophysics 48(3), 447-458.

Bintanja, R., 1999. On the glaciological, meteorological and climatological significance of Antarctic blue ice areas. Reviews in Geophysics 37, 3, 337-359.

Black, L., Kamo, S., Allen, C., Davis, D., Aleinikoff, J., Valley, J., Mundil, R.,Campbell, I., Korsch, R., Williams, I., Foudoulis, C., 2004. Improved ${ }^{206} \mathrm{~Pb} /{ }^{238} \mathrm{U}$ microprobe geochronology by the monitoring of a trace- element- related matrix effect; SHRIMP, ID-TIMS, ELA-ICPMS and oxygen isotope documentation for a series of zircon standards. Chemical Geology 205, $115-140$.

Bockheim, J.G., Wilson, S.C., Denton, G.H., Andersen, B.G., Stuiver, M., 1989. Late Quaternary ice-surface fluctuations of Hatherton Glacier, Transantarctic Mountains. Quaternary Research 31, 229-254.

Bromley, G.R.M., Hall, B.L., Stone, J.O., Conway, H., Todd, C.E., 2010. Late Cenozoic deposits at Reedy Glacier, Transantarctic Mountains: implications for former thickness of the West Antarctic Ice Sheet. Quaternary Science Reviews 29, 384-398.

Cassidy, W., Harvey, R., Schutt, J., Delisle, G., Yanai, K., 1992. The meteorite collection sites of Antarctica. Meteoritics 27, 490-525.

Chinn, T.J., 1991. Polar glacier margin and debris features. Memorie della Societ a Geologica Italiana 46, 25-44.

Cook, C.P., van de Flierdt, T., Williams, T., Hemming, S.R., Iwai, M., Kobayashi, M., JimenezEspejo, F.J., Escutia, C., González, J.J., Khim, B., McKay, R.M., Passchier, S., Bohaty, S.M., 
Riesselman, C.R., Tauxe, L., Sugisaki, S., Galindo, A.L., Patterson, M.O., Sangiorgi, F., Pierce, E.L., Brinkhuis, H., IODP Expedition 318 Scientists, 2013. Dynamic behavior of the East Antarctic ice sheet during Pliocene warmth. Nature Geoscience 6, 765-769.

Denton, G.H., Bockheim, J.G., Wilson, S.C., Stuiver, M., 1989. Late Wisconsin and Early Holocene glacial history, inner Ross Emabyment, Antarctica. Quaternary Research 31, 151-182.

Dupont, T.K., Alley, R.B., 2005. Assesment of the importance of ice-shelf buttressing to icesheet flow. Geophysical Research Letters 32, L04503.

Elliot, D.H., Fanning, C.M., 2008. Detrital zircons from upper Permian and lower Triassic Victoria Group sandstones, Shackleton Glacier region, Antarctica: evidence for multiple sources along the Gondwana plate margin. Gondwana Research 13, 259-274.

Elliot, D.H., Fanning, C.M., Hulett, S.R.W., 2014. Age provinces in the Antarctic craton: Evidence from detrital zircons in Permian strata from the Beardmore Glacier region, Antarctica. Gondwana Research 28, 152-164.

Encarnación, J., Fleming, T.H., Elliot, D.H., Eales, H.V. 1996. Synchronous emplacement of Ferrar and Karoo dolerites and the early breakup of Gondwana. Geology 24, 535-538.

Faure, G., Mensing, T.M., Johnson, K.S., 1992. Composition of rock clasts in the Mt. Achernar moraine and the Lewis Cliff ice tongue. Antarctic Journal of the U.S. 1992 Review, 11-12.

Faure, G., Mensing, T.M., 2010. The Transantarctic Mountains: Rocks, Ice, Metorites, and Water. Springer Science + Business Media B.V. doi: 10.1007/978-90-481-9390-5_10, 289-469.

Fitzgerald, P., 2002. Tectonics and landscape evolution of the Antarctic plate since the breakup of Gondwana, with an emphasis on the West Antarctic Rift System and the Transantarctic Mountains. Royal Society of New Zealand Bulletin 35, 453-469.

Fogwill, C.J., Hein, A.S., Bentley, M.J., Sugden, D.E., 2012. Do blue-ice moraines in the Heritage Range show that the West Antarctic Ice Sheet survived the last interglacial? Palaeogeography, Palaeoclimatology, Palaeoecology 335-336, 61-70.

Fretwell, P., Pritchard, H.D., Vaughan, D.G., Bamber, J.L., Barrand, N.E., Bell, R., Bianchi, C., Bingham, R.G., Blankenship, D.D., Casassa, G., Catania, G., Callens, D., Conway, H., Cook, A.J., Corr, H.F.J., Damaske, D., Damm, V., Ferraccioli, F., Forsberg, R., Fujita, S., Gogineni, P., Griggs, J.A., Hindmarsh, R.C.A., Holmlund, P., Holt, J.W., Jacobel, R.W., Jenkins, A., Jokat, W., Jordan, T., King, E.C., Kohler, J., Krabill, W., Riger-Kusk, M., Langley, K.A., Leitchenkov, G., Leuschen, C., Luyendyk, B.P., Matsuoka, K., Nogi, Y., Nost, O.A., Popov, S.V., Rignot, E., Rippin, D. M., Riviera, A., Roberts, J., Ross, N., Siegert, M. J., Smith, A.M., Steinhage, D., Studinger, M., Sun, B., Tinto, B. K., Welch, B.C., Young, D.A., Xiangbin, C., Zirizzotti, A., 2012. Bedmap2: improved ice bed, surface and thickness datasets for Antarctica. The Cryosphere Discussions 6, 4305-4361. 
Gehrels, G., Valencia, V., Pullen, A., 2006. Detrital zircon geochronology by laser-ablation multicollector ICPMS at the Arizona Laserchron Center. In: Loszewski, T., Huff, W. (Eds.), Geochronology, Emerging Opportunities, Paleontological Society Papers 12, 67-76.

Gehrels, G., Valencia, V., Ruiz, J., 2008. Enhanced precision, accuracy, efficiency, and spatial resolution of $\mathrm{UePb}$ ages by laser ablation-multicollector-inductively coupled plasma-mass spectrometry. Geochemistry, Geophysics, Geosystems 9, Q03017. http://dx.doi.org/10.1029/2007GC001805.

Gehrels, G., 2012. Detrital zircon U-Pb geochronology: current methods and new opportunities. In: Busby, C., Azor, A. (Eds.), Tectonics of Sedimentary Basins: Recent Advances. Blackwell Publishing, pp. 47-62.

Goodge, J.W., Vervoort, J.D., Fanning, C.M., Brecke, D.M., Farmer, G.L., Williams, I.S., Myrow, P.M., DePaolo, D.J., 2008. A positive test of East Antarctica-Laurentia juxtaposition within the Rodia Supercontinent. Science 321, 235-240.

Goodge, J.W., Fanning, C.M., Norman, M.D., Bennett, V.C., 2012. Temporal, isotopic and spatial relations of Early Paleozoic Gondwana-margin arc magmatism, central Transtantarctic Mountains, Antarctica. Journal of Petrology 53, 2027-2065.

Greenbaum, J.S., Blankenship, D.D., Young, D.A., Richter, T.G., Roberts, J.L., Aitken, A.R.A., Legresy, B., Schroeder, D.M., Warner, R.C., van Ommen, T.D., Siegert, M.J., 2015. Ocean access to a cavity beneath Totten Glacier in East Antarctica. Nature Geoscience 8, 294-298.

Hagen, E.H., 1995. A geochemical and petrological investigation of meteorite ablation products in till and ice of Antarctica. Ph.D. dissertation, The Ohio State University, Columbus, OH, USA.

Hall, B.L., Denton, G.H., Stone, J.O., Conway, H., 2013. History of the grounded ice sheet in the Ross Sea sector of Antarctica during the Last Glacial Maximum and the last termination. Geological Society, London, Special Publication 381, 167-181.

Hammer, Ø., Harper, D.A.T., Ryan, P.D., 2001. PAST: paleontological statistics software package for education and data analysis. Palaeontologia Electronica 4, 1-9. http://palaeoelectronica.org/2001_1/past/issue1_01.htm.

Hättestrand, C., Johansen, N., 2005. Supraglacial moraines in Scharffenbergbotnen, Heimefrontfjella, Dronning Maud Land, Antarctica - significance for reconstructing former blue ice areas. Antarctic Science 17, 225-236.

Hein, A.S., Woodward, J., Marreo, S.M., Dunning, S.A., Steig, E.J., Freeman, S., Stuart, F.M., Winter, K., Westoby, M.J., and Sugden, D.E., 2016. Evidence for the stability of the West Antarctic ice sheet divide for 1.4 million years. Nature Communications 7, DOI: 10.1038/ncomms 10325 . 
Hodgson, J., Licht, K.J, Swope, J., 2013. Affirmation of Antarctic-Laurentian Rodinian Juxtaposition During the MesoProterozoic. Geological Society of America Abstracts with Programs 45, 7, p. 585.

Hollin, J.T., 1962. On the glacial history of Antarctica. Journal of Glaciology 4, 173-195.

Isbell, J.L., 1990. Fluvial sedimentology and basin analyses of the Permian Fairchild and Buckley Formations, Beardmore Glacier region, and the Weller Coal Measures, Southern Victoria Land, Antarctica. PhD dissertation Ohio State Univ., Columbus, OH, USA.

Isbell, J.L., 1999. The Kukri Erosion Surface; a reassessment of its relationship to rocks of the Beacon Supergroup in the central Transantarctic Mountains, Antarctica. Antarctic Science 11, 288-238.

Isbell, J.L., Koch, Z.J., Szablewski, G.M., Lenaker, P.A., 2008. Permian glacigenic deposits in the Transantarctic Mountains, Antarctica. Geological Society of America Special Paper 441, 5970 .

Joughin, I., Alley, R.B., 2011. Stability of the West Antarctic ice sheet in a warming world. Nature Geoscience 4, 506-513.

Kaplan, M., Licht, K., Winckler, G., Schaefer, J., Mathieson, C., Bader, N., 2014. Blue Ice Moraines as an Archive of Past EAIS dynamics: Mt. Achernar as a Case Study in the Central Transantarctic Mountains. Abstract PP21A-1310, AGU, San Francisco, CA., 15-19 Dec.

Licht, K.J., Palmer, E.F., 2013. Erosion and transport by Byrd Glacier, Antarctica during the Last Glacial Maximum. Quaternary Science Reviews 62, 32-48.

Licht K.J., Hennessy, A.J., Welke, B.M., 2014. The U/Pb detrital zircon signature of West Antarctic ice stream tills in the Ross Embayment, with implications for LGM ice flow reconstructions. Antarctic Science 26, 687-697.

Ludwig, K.R., 2003. Isoplot 3.00: Berkeley Geochronology Center, Special Publication, 4, 70 p.

Mathieson, C., Kaplan, M.R., Winckler, G., Schaefer, J., Licht, K.J., Bader, N., Dits, T., 2012. Cosmogenic Dating of Moraines in the Central Transantarctic Mountains to Evaluate Past Behavior of the East Antarctic Ice Sheet. Abstract PP23C-2071, AGU, San Francisco, CA., 3-7 Dec.

Mercer, J.H., 1968. Glacial geology of the Reedy Glacier area, Antarctica. Geological Society of America Bulletin 79, 471-486.

Mercer, J.H., 1972. Some observations on the glacial geology of the Beardmore Glacier area. In: Adie, R.J. (Ed.), Antarctic Geology and Geophysics. Universitetsforlaget, Oslo, pp. 427-433.

Mercer, J.H., 1983. Cenozoic glaciation in the southern hemisphere. Annual Reviews Earth Planetary Science 11, 99-132. 
Palmer, E.F., Licht, K.J., Swope, R.J., Hemming, S.R., 2012. Nunatak moraines as a repository of what lies beneath the East Antarctic ice sheet. In: Rasbury, E.T., Hemming, S.R., Riggs, N.R. (Eds.), Mineralogical and Geochemical Approaches to Provenance. Geological Society of America Special Paper 487, pp. 97-104. http://dx.doi.org/10.1130/2012.2487(05)

Paulsen, T.S., Encarnación, J., Grunow, A.M., Valencia, V.A., Pecha, M., Layer, P.W.

Rasoazanamparany, C., 2013. Age and significance of 'outboard' high-grade metamorphics and intrusives of the Ross orogen, Antarctica. Gondwana Research 24, 349-358.

RAISED Consortium, 2014. A community-based geological reconstruction of Antarctic ice sheet deglaciation since the Last Glacial Maximum. Quaternary Science Reviews 100, 1-9.

Rignot, E., Mouginot, J., Morlighem, M., Seroussi, H., Scheuchl, B., 2014. Widespread, rapid grounding line retreat of Pine Island, Thwaites, Smith, and Kohler glaciers, West Antarctica, from 1992-2011. Geophysical Research Letters 41, 3502-3509.

Scarrow, J.W., Balks, M.R., Almond, P.C., 2014. Three soil chronosequences in recessional glacial deposits near the polar plateau, in the Central Transantarctic Mountains, Antarctica. Antarctic Science 26, 573-583.

Siegert, M.J., Carter, S., Tobacco, I., Popov, S., Blankenship, D.D., 2005. A revised inventory of Antarctic subglacial lakes. Antarctic Science 17, 53-460.

Stearns, L.A., Smith, B.E., Hamilton, G.S., 2008. Increased flow speed on a large East Antarctic outlet glacier caused by subglacial floods. Nature Geoscience 1, 827-831.

Stump, E., 1995. The Ross Orogen of the Transantarctic Mountains. Cambridge University Press, 284 p.

Whillans, I.M., Cassidy, W.A., 1983. Catch a falling star: Meteorites and old ice: Science 222, 55-57.

Wingham, D.J., Siegert, M.J., Shepherd, A., Muir, A.S., 2006. Rapid discharge connects Antarctic subglacial lakes. Nature 440, 1033-1036. 

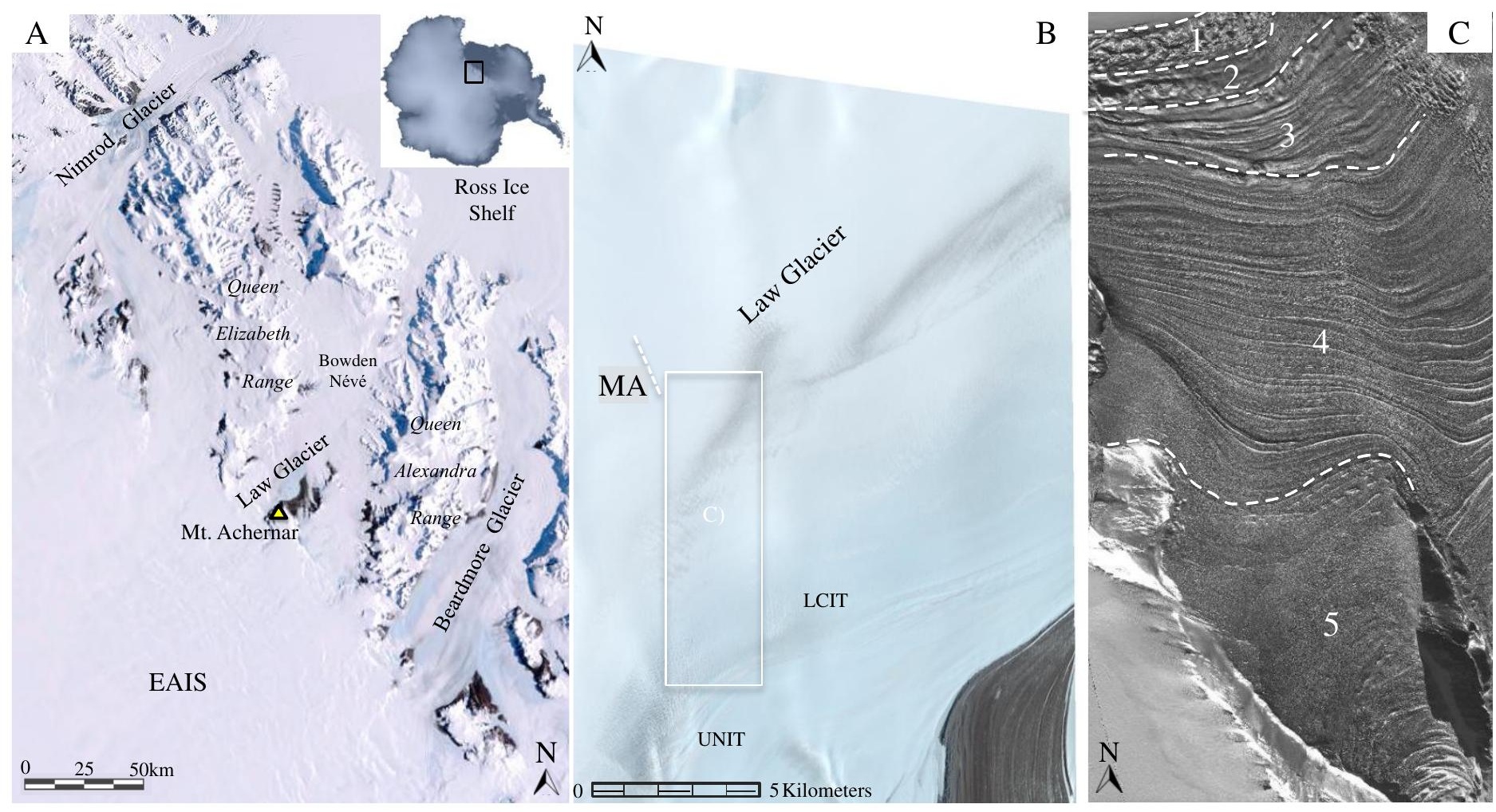

Figure 1. Study area in the central Transantarctic Mountains. A) regional map highlighting the location of Mt. Achernar at the inland margin of the TAM where flow transitions from unconstrained East Antarctic Ice Sheet (EAIS) flow into the Law Glacier. B) Mt. Achernar moraine where primary sediment input is from the Law Glacier; dashed line indicates location a lateral moraine at the base of Mt. Achernar. Two ice tongues (MA - Mt. Achernar, UNIT - unnamed ice tongue and LCIT - Lewis Cliff ice tongue) impinge on the southern margin of the moraine. C) Numbered zone boundaries highlight geomorphic transition from hummocky topography near Law Glacier (zone 1) to welldeveloped parallel ridges/troughs in zone 4 . Zone 5 ridges curve toward the south showing sediment input from the unnamed ice tongue. Imagery from DigitalGlobe provide by the PGC. 


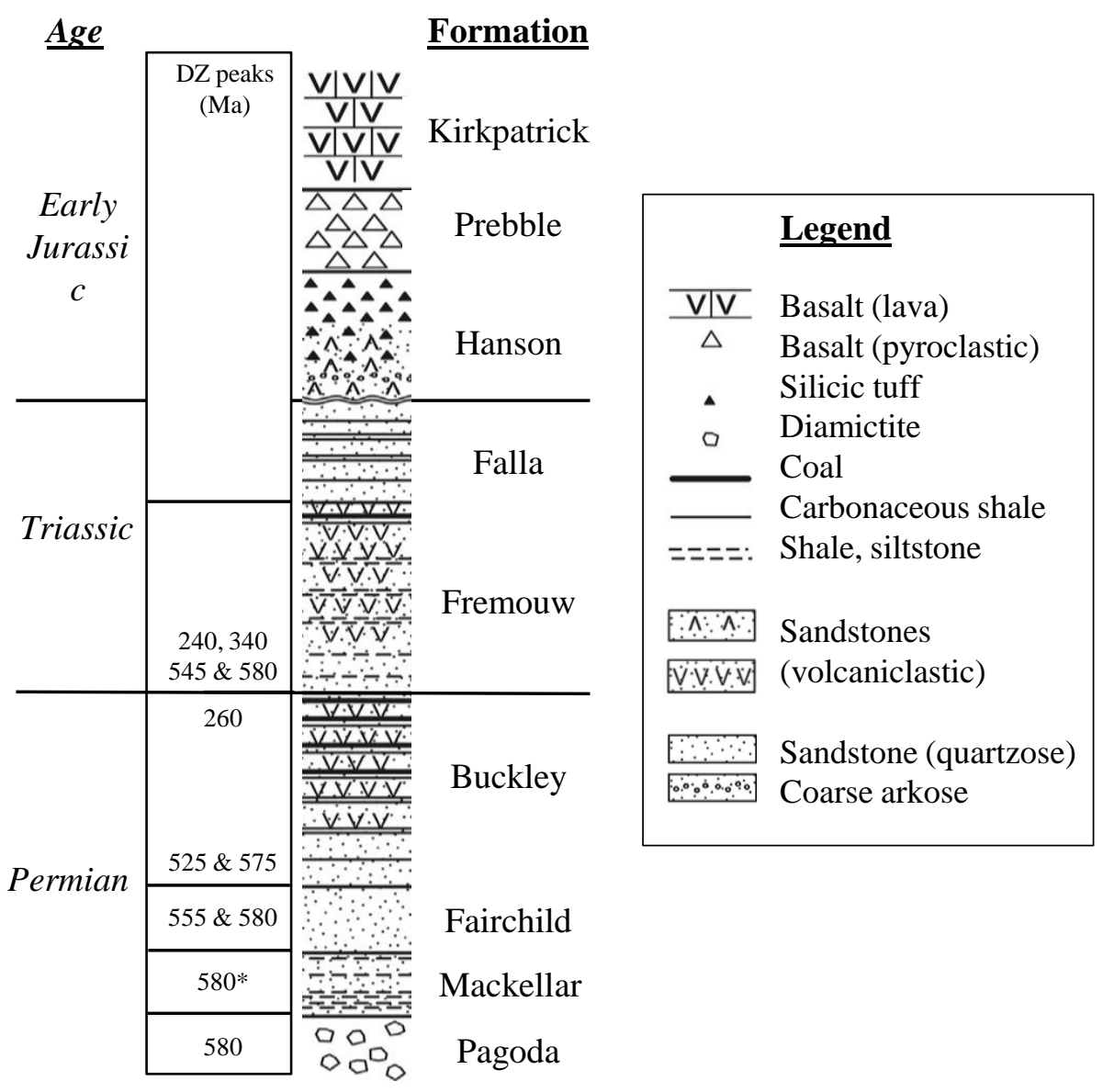

Figure 2. Simplified stratigraphic column of the Beacon Supergroup from the central Transantarctic Mountains along with dominant detrital zircon (DZ) age peaks from this study* and Elliot and Fanning, 2008 and Elliot et al., 2014. See Supplementary Figure 1 for complete zircon age distributions. (Modified from Elliot et al., 2014.) 

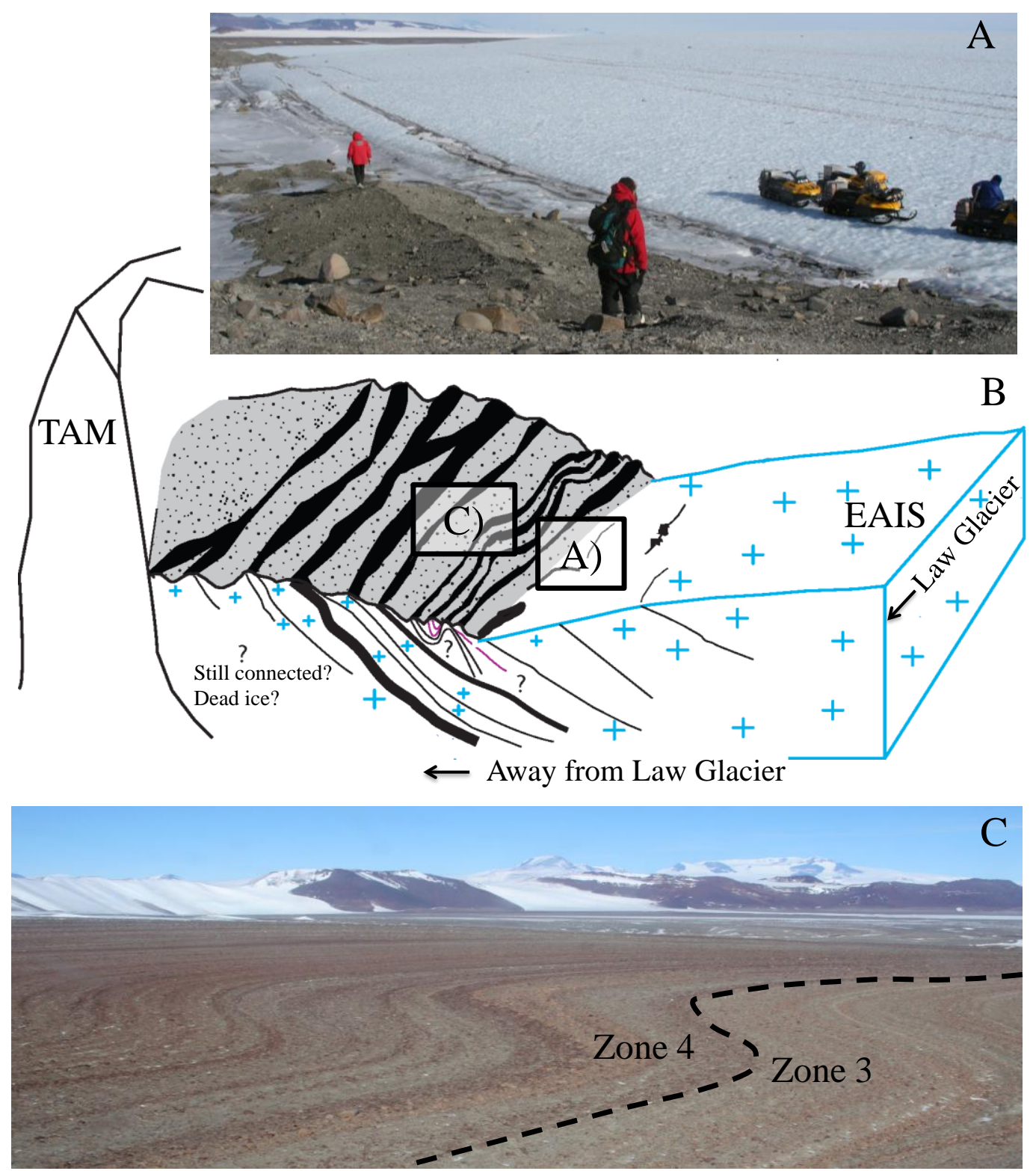

Figure 3. Conceptual model of the setting of the Mt. Achernar moraine (gray shaded area) adjacent to Law Glacier draining the East Antarctic Ice Sheet (B). Photos from the site highlight numerous emerging debris bands at the edge of the moraine (A) and distinctlycolored debris bands in zone 4 (C). 


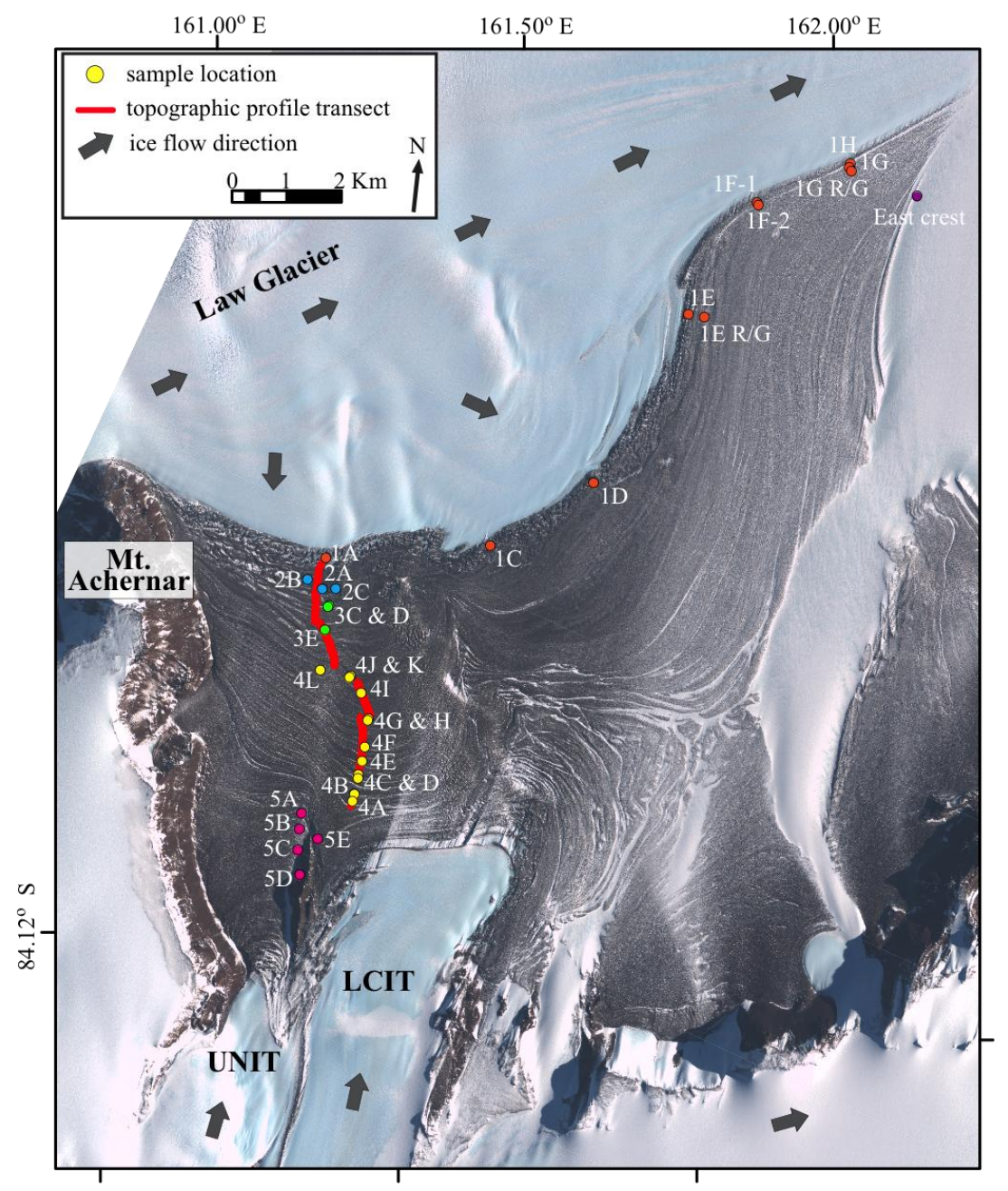

Figure 4. Mt. Achernar moraine with topographic profile transect (shown in Figure 5) delineated by a red line and sample locations shown by dots (colored by zone). Zone 1 samples are along this transect as well as downstream along the debris/ice boundary (the 'tail'). Note that zone 5 samples are sourced by the UNIT rather than Law Glacier. Gray arrows indicate ice flow direction. Blue ice of the Law Glacier is the primary source of debris to the moraine. Two ice tongues impinge locally on the moraine; UNIT = unnamed ice tongue and LCIT = Lewis Cliff Ice Tongue. Imagery from DigitalGlobe provide by the PGC. 
Mt. Achernar Moraine topographic profile

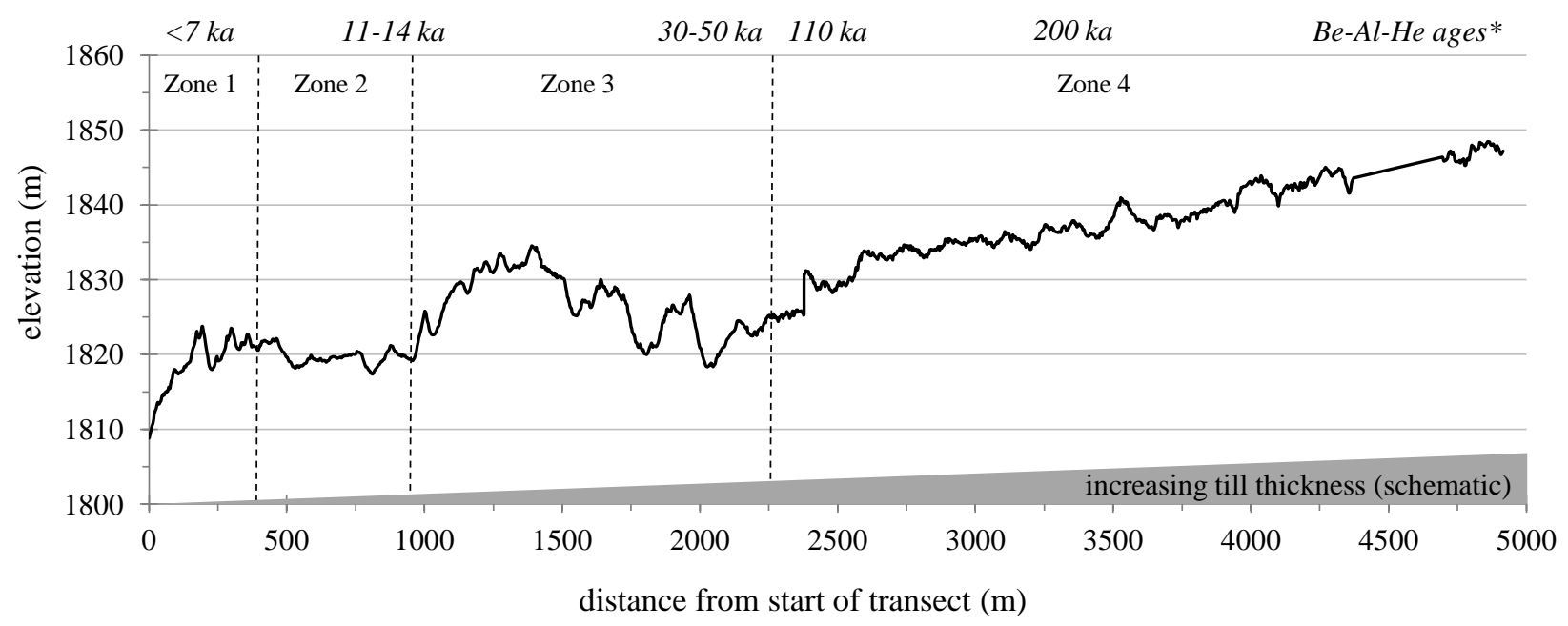

Figure 5. Topographic profile from the Law Glacier (left) across the Mt. Achernar moraine by a differentially processed Trimble Rover GPS system (see Fig. 4 for transect location). Zone 2 shows the least relief and Zone 3 has a broad $15+\mathrm{m}$ arch with superimposed ridges. Increasing till thickness is shown schematically and ranges from $<1$ to $>50 \mathrm{~cm}$ thick. Be-Al-He ages* are from Mathieson et al. (2012) and Kaplan et al. (2014). 


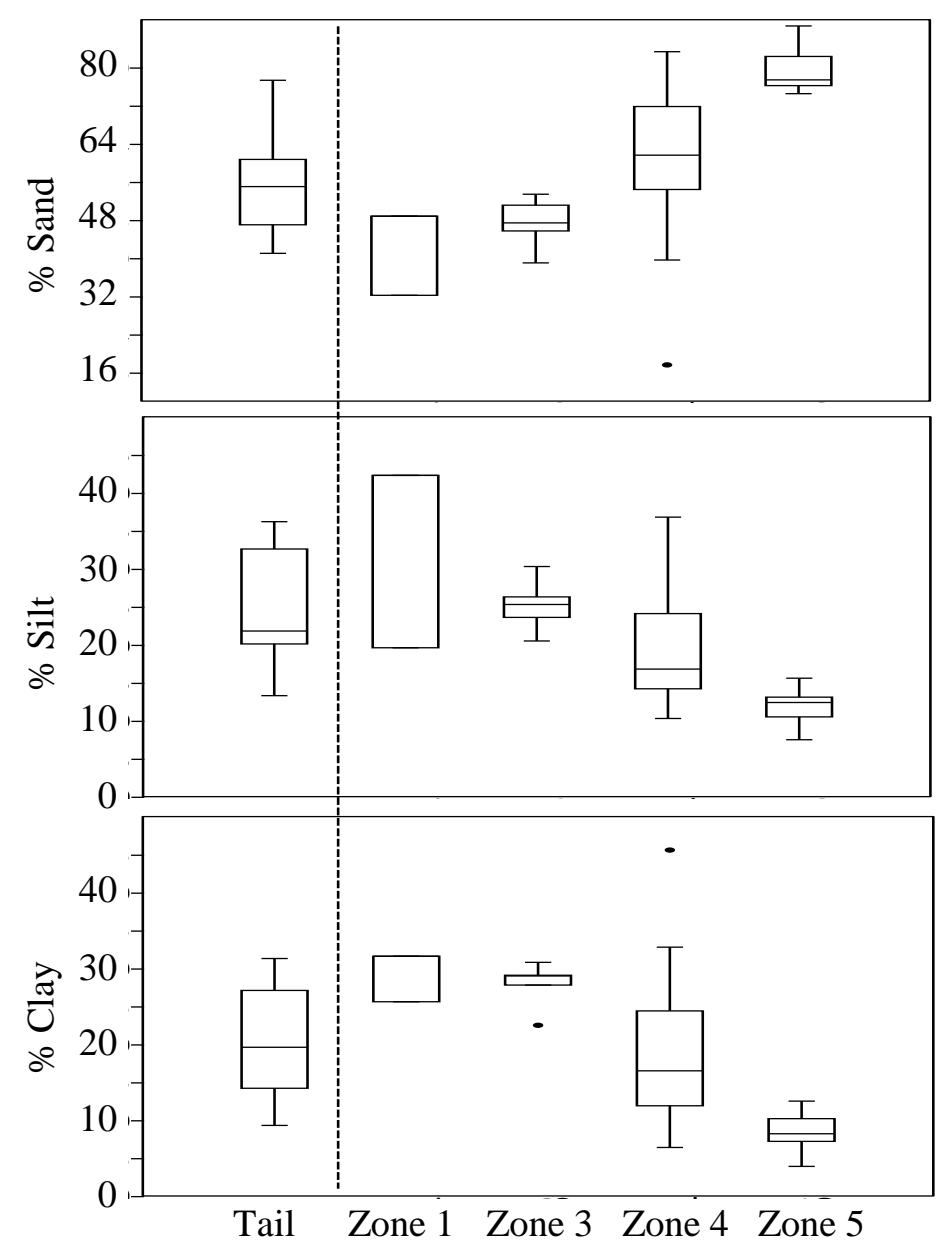

Figure 6. Box plots of $<2 \mathrm{~mm}$ particle size data by zone (Table 2). The box outlines the middle $50 \%$ of data ( $2^{\text {nd }}$ and $3^{\text {rd }}$ quartiles), the line inside the box represents the median value of the whole data set, and the whiskers show the greatest/least values excluding the outliers, which are defined as data that is greater than 1.5 times the box height. Zone 2 is not included in box plots because only one sample was collected. Dashed line separates tail samples from main transect samples. Tail $n=10$, Zone 1 along transect $n=2$, Zone $3 n=6$, Zone $4 n=12$, Zone $5 n=5$. 

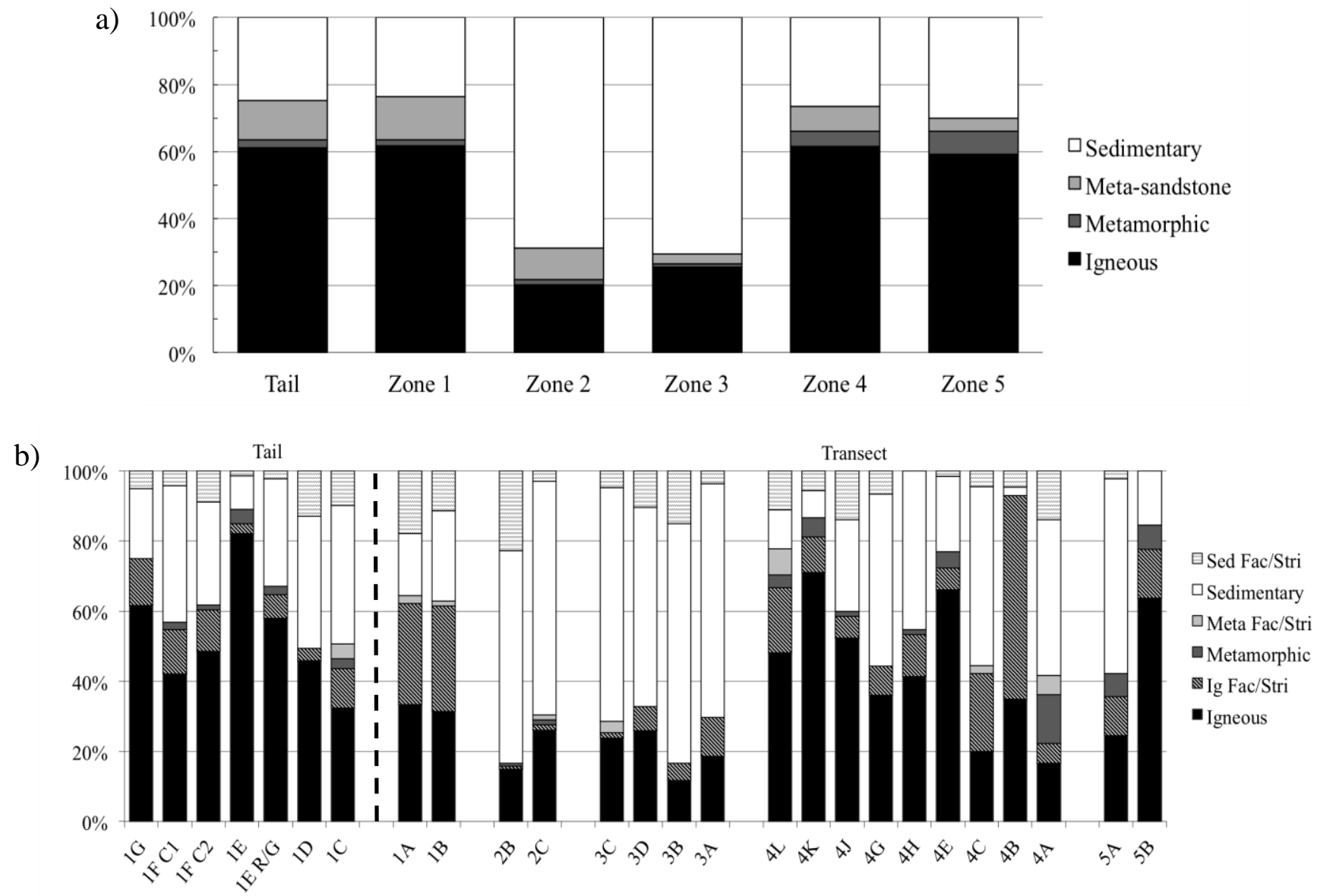

Figure 7. Pebble compositions of the Mt. Achernar moraine by zone and sample.

a) Percent lithology by zone emphasizing relatively low abundance of Ferrar dolerite (igneous) rocks in zones 2 and 3; b) Percentage of pebble types present in each sample from the tail and transect, including proportion faceted and/or striated. Each sample reflects rocks collected from $1 \mathrm{~m}^{2}$. See Supplementary Table 1 for the classification scheme used to categorize pebbles. 


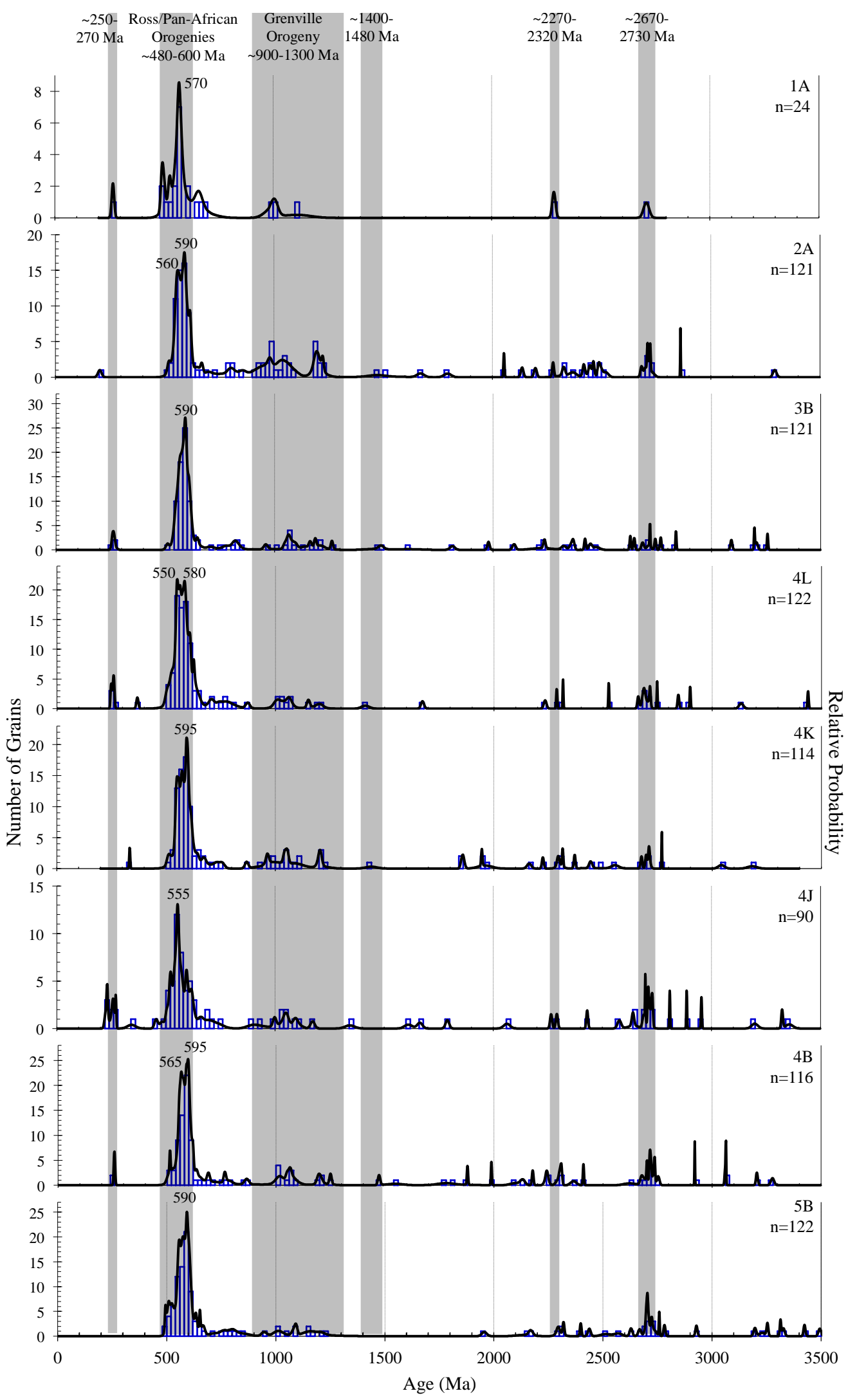

Figure 8a. Normalized probability plots and histograms of Mt. Achernar moraine tills; sample names are on the right. Known geologic events and ages of interest are highlighted in gray (see Section 2). 


\section{Bedrock samples}
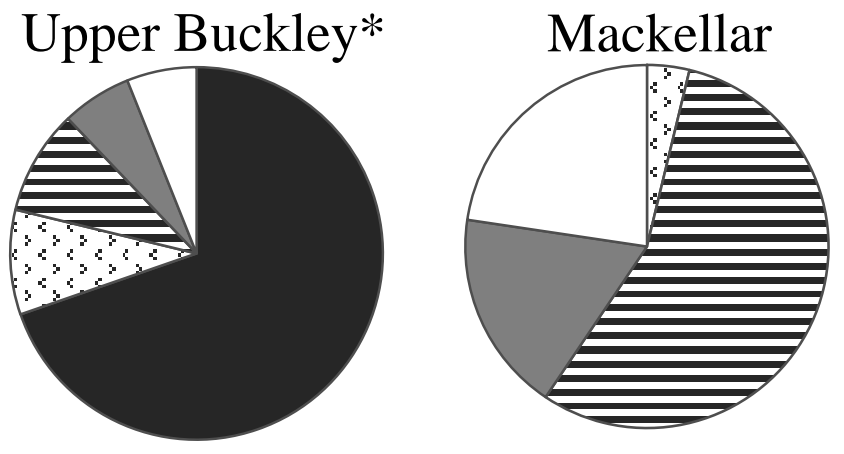

\section{Zircon age groups \\ a $<300 \mathrm{Ma}$}

. $450-550 \mathrm{Ma}$

目 550-650 Ma

Lower Buckley*

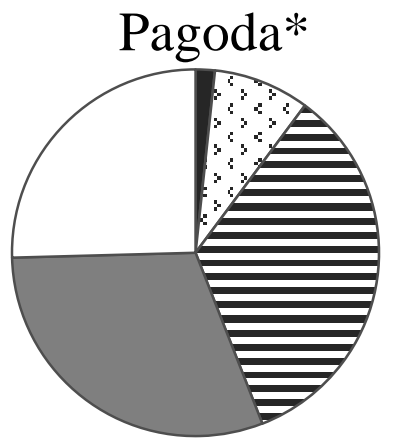

900-1300 Ma

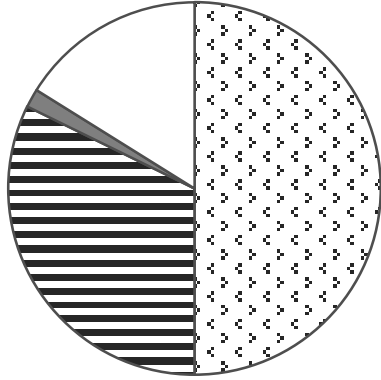

Pagoda
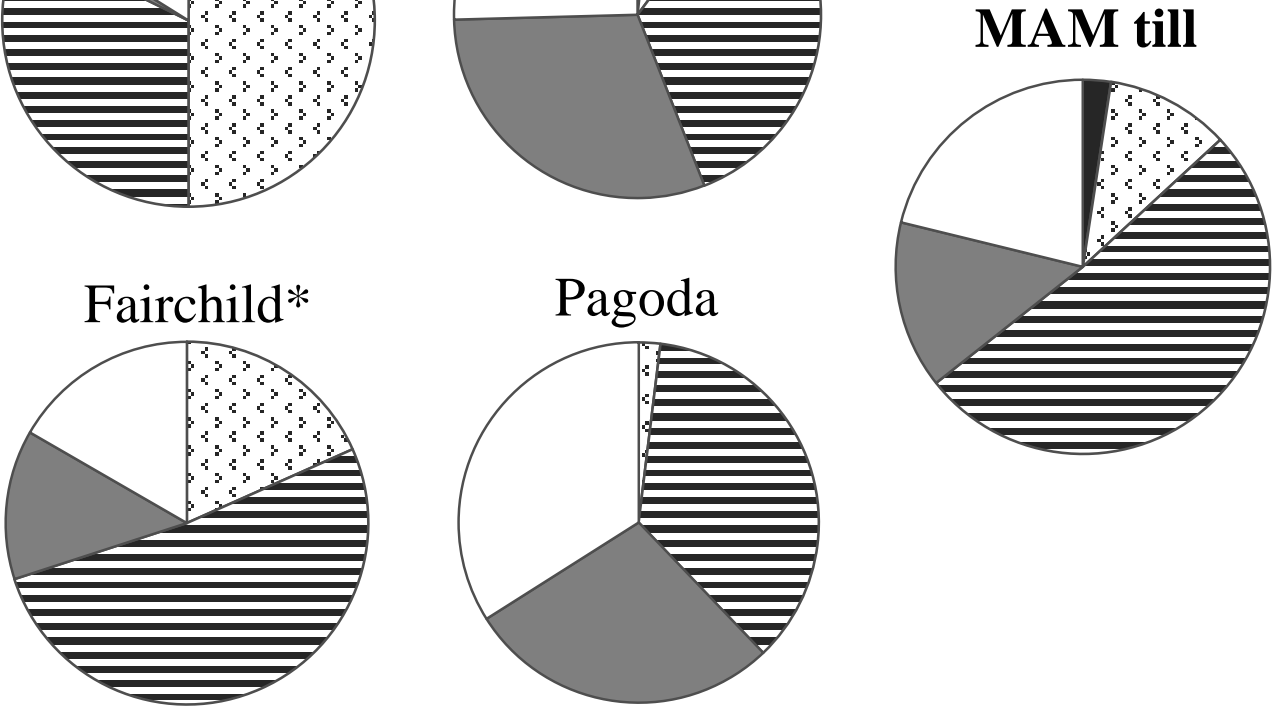

Figure $8 \mathrm{~b}$. Pie diagrams comparing samples of potential sources from Beacon Supergroup bedrock (left two columns) with MAM till (on the right). The age groups highlight the proportion of grains in zircon age groups with particular provenance significance. Some bedrock samples* are from Elliot and Fanning, 2008 or Elliot et al., 2014 and other bedrock samples and till samples are from this study. The Achernar till populations are most similar to the Fairchild, Mackellar and Pagoda Formations and least similar to the Buckley Formation, which is the locally outcropping bedrock. 
Time-transgressive deposits from Law Gl. access progressively lower Beacon strata

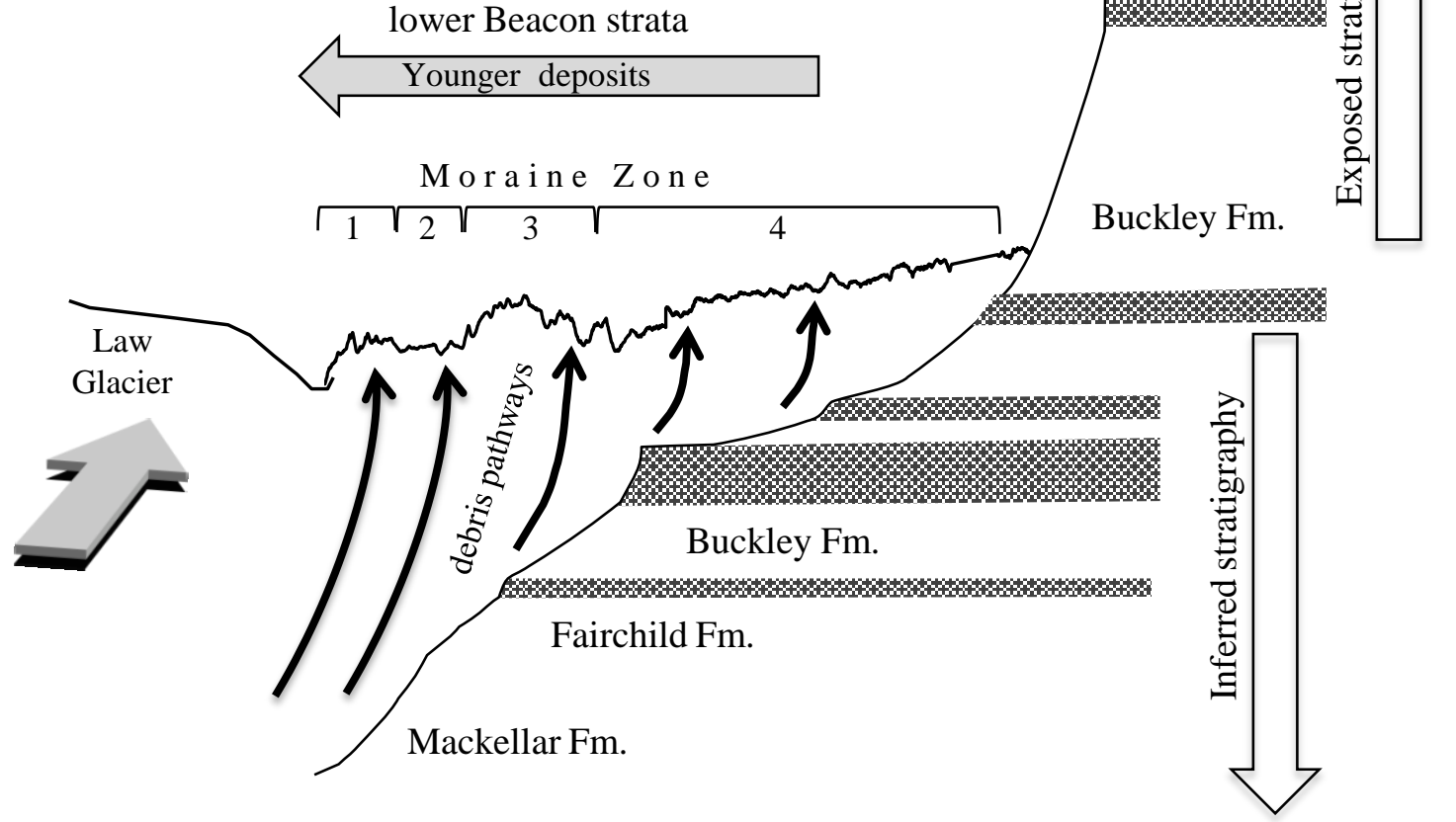

Figure 9. Conceptual model of the formation of the Mt. Achernar Moraine showing the exposed $800 \mathrm{~m}$ thick bedrock section (Faure and Mensing, 2010) and inferred (ice-covered) bedrock stratigraphy along with the measured moraine topographic profile (Fig. 5). Dark horizontal bands represent Ferrar dolerite sills, three of which are exposed. Black arrows show hypothesized debris transport pathways that explain the source of compositional changes in till across the moraine This model highlights the sub- and englacial origin of the moraine sediment and spatio-temporal shift to debris sources lower in the bedrock stratigraphic section as new till accumulated toward what is the present day Law Glacier margin. 


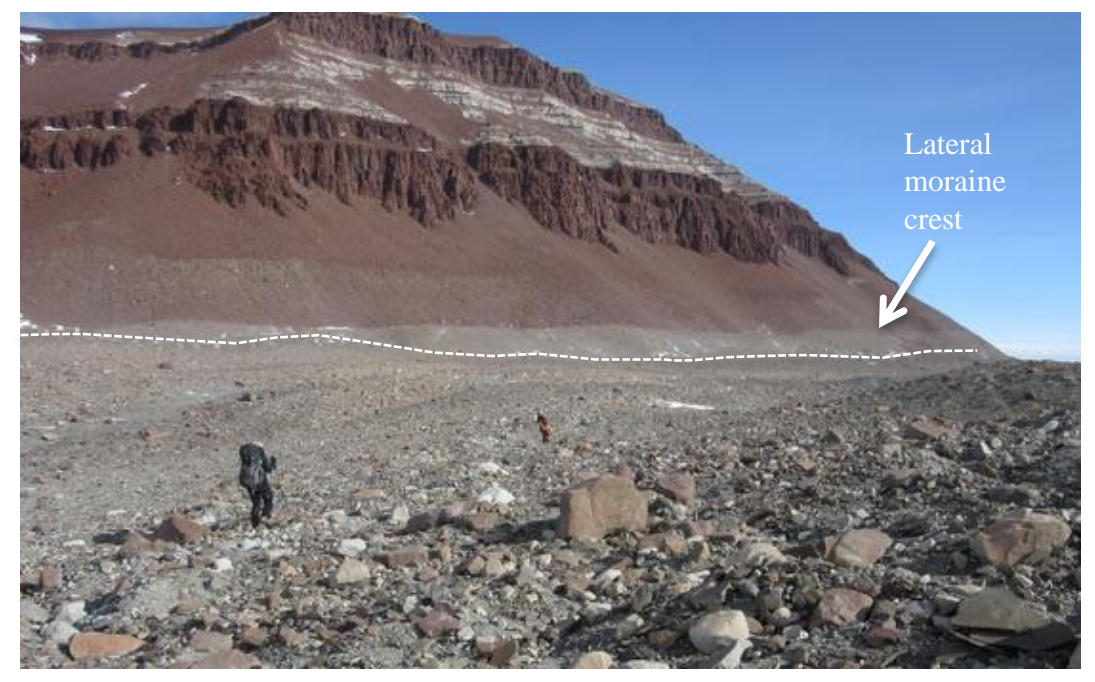

Figure 10. Photograph of lateral moraine created by Law Glacier at the base of Mt. Achernar.

White dashed line highlights the MAM surface. 